THE GRADUATE INSTITUTE I GENEVA

INSTITUT DE HAUTES ETUDES

INTERNATIONALES ET DU DÉVELOPPEMENT

GRADUATE INSTITUTE OF INTERNATIONAL

AND DEVELOPMENT STUDIES

Graduate Institute of

International and Development Studies Working Paper No: 08/2010

\author{
Hamlet Without the Prince of Denmark: \\ RELATIONSHIP BANKING AND CONDITIONALITY LENDING IN THE LONDON \\ MARKET FOR FOREIGN GOVERNMENT DEBT, 1815-1913
}

\author{
Marc Flandreau \\ The Graduate Institute, Geneva \\ Juan Flores \\ University of Geneva
}

\begin{abstract}
This paper offers a theory of conditionality lending in $19^{\text {th }}$ century international capital markets. We argue that ownership of reputation signals by prestigious banks rendered them able and willing to monitor government borrowing. Monitoring was a source of rent, and it led bankers to support countries facing liquidity crises in a manner similar to modern descriptions of "relationship" lending to corporate clients by "parent" banks.

Prestigious bankers' ability to implement conditionality loans and monitor countries' financial policies also enabled them to deal with solvency. We find that, compared with prestigious bankers, bondholders' committees had neither the tools nor the prestige required for effectively dealing with defaulters. Hence such committees were far less important than previous research has claimed.
\end{abstract}

(C) The Authors.

All rights reserved. No part of this paper may be reproduced without the permission of the authors. 
Hamlet Without the Prince OF DenMark:

\title{
RELATIONSHIP BANKING AND CONDITIONALITY LENDING IN THE LONDON MARKET FOR \\ FOREIGN GOVERNMENT DEBT,
}

1815-1913

\author{
Marc Flandreau and Juan Flores*
}

This draft: June 2010

\begin{abstract}
This paper offers a theory of conditionality lending in $19^{\text {th }}$-century international capital markets. We argue that ownership of reputation signals by prestigious banks rendered them able and willing to monitor government borrowing. Monitoring was a source of rent, and it led bankers to support countries facing liquidity crises in a manner similar to modern descriptions of "relationship" lending to corporate clients by "parent" banks. Prestigious bankers" ability to implement conditionality loans and monitor countries" financial policies also enabled them to deal with solvency. We find that, compared with prestigious bankers, bondholders' committees had neither the tools nor the prestige required for effectively dealing with defaulters. Hence such committees were far less important than previous research has claimed.
\end{abstract}

\footnotetext{
* Graduate Institute, Geneva, and the University of Geneva (respectively). We are grateful to Vincent Bignon and Larry Neal for comments on earlier drafts and for helping us focus the argument. We thank Peter Lindert for fruitful exchanges over recovery rates. They should be absolved of our shortcomings. The help and support of archivists (in particular, the ING Barings Archive and the Rothschilds Archive in London) is gratefully acknowledged.
} 


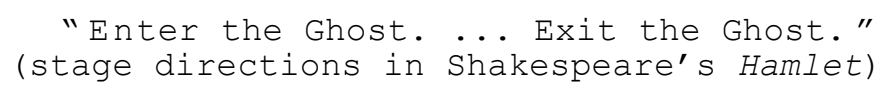

This paper develops an analysis of conditionality lending during the long era of London-based "globalized" foreign government debt markets that ended at the start of World War I. The argument we make is that the concepts and insights from modern relationship banking theory provide powerful tools for understanding how international capital markets could exact "structural adjustment" from borrowing governments. In a nutshell, this occurred because of market structure. A few prestigious intermediaries owned the ability to "certify" a borrowing government, which enabled them to influence the terms of market access. The intermediaries thus had a measure of monopoly power over borrowers and used it to obtain adjustments that increased the likelihood of repayment. Conditionality lending was an investment in the prestigious bankers' own brand. This explains why prestigious banks were both able and willing to manage their clients' liquidity crises.

The starting point of this new view is earlier research by Flandreau and Flores (2009) providing analytical insights on, and empirical evidence of, the role of capital, prestige, and market share as collaterals in the foreign government bond markets that developed in London in the early 1820s. Here we seek to expand the range of the argument both analytically and historically. First, we argue that "rules of the game" similar to those that operated in the early 1820 s were also in force in subsequent periods and, in fact, apply to the entire Pax Britannica era (1815-1913). Second, we show how the signaling role (emphasized in our previous research) was combined with control. Third, we show how focus on control does provide a theoretical clarification of the logic of conditionality lending to $19^{\text {th }}$ century foreign governments.

An important aspect of our theory (if not the main one) is that it departs from conventional thinking in recent historical research on sovereign debt. The dominant mode of thinking has been to emphasize three alternative modes of governing sovereign debt: bondholder activism, high-quality domestic institutions, and imperial influence. In this paper, we abstract from the role of imperial influence, whose invocation amounts to assuming the problem away. External imperial control means that sovereign debt is not sovereign at all, explaining why the debts of colonies have been generally and rightly perceived as less risky by investors. ${ }^{1}$ We also abstract from domestic institutions and the North-Weingast veto-point theme, since this is simply another approach to assuming the problem away. There are many real-world examples of when "desirable" institutions were not present and yet lending occurred. When, say, Argentina or (as Nathaniel de Rothschild put it) "the Khan of Khiva, or ... any of those States" were borrowing, they were likely to default and did. $^{2}$ In such cases, markets had to deal with the resulting mess. We therefore investigate the situation of countries for which neither imperial control nor appropriate domestic institutions (whatever may be meant by that) were available.

\footnotetext{
${ }^{1}$ See Accominotti, Flandreau, and Rezzik (2010) for a study and survey of default risk in British colonies.

${ }^{2}$ Select Committee (1875, p. 268).
} 
Previous research has suggested that the "solution" to these problems would have been the emergence of bondholders' committees (such as the British Corporation of Foreign Bondholders of 1868) to coordinate creditors' activism and perhaps increase the odds of sovereign repayment. ${ }^{3}$ To the casual observer it seems that bondholders' committees were the only available mechanism to deal with default, so their operation attracted considerable research interest; a few equations later down the road, authors grew accustomed to seeing these committees as the engine of successful sovereign debt in the $19^{\text {th }}$ century. However, focusing on bondholders while ignoring the rest of the cast is analogous to putting on Hamlet without the Prince of Denmark. In the global financial game, the lead is played by the international banker. Bondholders set the drama into action by seeking revenge (thus playing the Ghost's role in Hamlet), but the instrument of revenge (the Prince) was the banker.

The language of corporate finance theory provides a natural way to think of bankers and how their actions differed from those of bondholders' committees: to distinguish creditors' committees from international bankers, one may liken their respective roles to "direct" monitoring by shareholders and "delegated" monitoring by a parent bank. These alternative institutions perform in different ways, address different informational problems, and are therefore optimal in different settings. It is often emphasized that bank monitoring becomes optimal when control through shareholder assemblies fails. Shareholder assemblies can fail when they prove unable to acquire relevant information from the agent (borrower) or because coercion is impossible owing to such collective action problems as inability to coordinate and free-riding. In such instances (and if some additional conditions are met), delegated monitoring through a bank may be the superior arrangement. ${ }^{4}$

In order for underwriting banks to play a role in our tale, there must have been some aspects to their organization that ensured value would be created by their intervention. On this account, our previous joint research establishes that, in the early $19^{\text {th }}$ century, certain underwriters could add value because of their reputation or prestige. Prestige enabled bankers to own a large market share and would have been lost had they cheated investors. This finding addresses the contracting "externality" that prior research had argued is a key weakness of international debt and bondholders' collective action. Thus, monitoring by reputable banks rested on imperfect competition. In other words, even before the bondholders could organize themselves as a cartel, a mechanism for concentrating lending

\footnotetext{
${ }^{3}$ Bondholders' committees must also be distinguished from imperial influence. The committees lobbied British policy makers to use their gunboats and diplomatic facilities, but the policy makers feared moral hazard and diplomatic complications. The reason, as emphasized by Platt (1968), was that military intervention was usually not feasible because it risked triggering hostile reactions from rival powers. As The Economist (14 November 1868, p. 1301) stated when the Corporation of Foreign Bondholders was founded: "we should be damaged by the result of the meeting held to-day if it went forth that the meeting have endorsed the view that it is the duty of the English government to compel foreign Governments to pay the debts incurred to English subjects. If the Government were to go to war for such a purpose with Venezuela, they would involve themselves in this position - that if larger powers should act in the same way, they should also go to war with them. I think it is dangerous to have the idea go forth that when an Englishman lends his money to a foreign Government he is creating a national obligation, guaranteed by the full weight of the English government."

${ }^{4}$ Diamond (1984), Fama (1985). Tirole (2002) adapts these concepts to the modern period's international financial system.
} 
authority existed "naturally" in the underwriting market. We shall argue that there are reasons to believe this natural monopoly or oligopoly probably outweighed what bondholders could do, given the latter's tendency to free-ride. Moreover, although bondholders' committees may have carried sticks (they could, in principle, prevent countries from borrowing in the market to which they were affiliated), they had no carrots; because they were not in the lending business, they could not, for instance, rescue a borrower facing an illiquidity crisis.

In contrast, prestigious underwriters did have such power. While entirely neglected in the recent macroeconomic literature, this theme has been popular with some previous business historians who previously suggested that prestige did play a role in foreign debt underwriting (See, for example, Hidy (1949) on Barings, Gille $(1965,1967)$ on Rothschilds, and Suzuki (1994) on Japanese government finance). In this paper, we seek to systematize these earlier intuitions by providing a rigorous framework to handle them. In particular, rather than focusing on specific banking houses or borrowers, we characterize the general landscape in which borrowers and banking houses interacted. Moreover, we articulate a theory to explain why prestige played a role in crisis lending. We argue that prestige and market power earned some bankers an informational rent on country-specific knowledge and put them in a convenient position to deal with payment crises. They could decide whether a given country was experiencing a liquidity or solvency crisis and then address it. We suggest prestige gave rise to a type of bargaining between lenders and borrowing governments that is similar to that described in "relationship banking" models. These models study the reasons for the emergence of repeated interactions between banks and corporate borrowers (as in today's Japanese system of main banks or in the German system of universal banks). The traditional argument for relationship banking is that banks have comparative advantages in corporate monitoring. An important theoretical insight is the role of liquidity provision. The main bank is expected to provide support to its clients in difficult times because of (among other things) greater signalling power. A corollary is that the bank acts not only through signaling but also through control. The main bank can deliver value by enforcing proper policies and creating incentives for organizational reform when needed. Of course, the resulting policies need not be conducive to growth or development; they need only protect the underwriter's reputation for successful monitoring. This may explain why some earlier historians have used the language of imperialism to describe the relation between banking houses and borrowers.

It is unclear why the international banker has been omitted from the picture in recent years. One reason may involve a theoretical prejudice-namely, the popularity of the free-riding argument. Researchers have generally doubted that underwriting banks would ever be able to manage their conflicts of interest. An explicit statement to that effect is given by Eichengreen and Portes: "bondholders recognized ... that the issuing house was likely to be torn apart between the interests of two sets of customers: bondholders and foreign borrowers. ... Given the potential for conflict of interest, most readjustments were therefore negotiated not by issuing houses but by independent committees" (1986, p. 621). These remarks ostensibly apply to the interwar order, but they have $19^{\text {th }}$ - 
century roots. For instance, The Economist wrote in 1897 about the powerful influence of issuing houses "who find it practically impossible to do fresh business with the debtors while the default lasts, and who are therefore, naturally anxious that some sort of settlement should be arrived at, more especially as settlements of the kind ... are frequently followed by new loans."

Another explanation for the general neglect of the underwriting banks' role may be the historical context in which the recent literature originated. Research on the history of international debt was sparked by the 1980s international debt crisis. At that time, it was clear that large U.S. banks had failed to monitor the risks of their own portfolio of commercial loans. This fact cast doubt on the capacity of intermediaries to screen (let alone to signal). Finally, it must be said that much of the action relevant to our argument occurred in places that cannot be easily observed (given the "radar" targets of recent economic historians). Indeed, by providing support to illiquid governments, bankers helped prevent problems from reaching the market. Cases that became known tended to be, by construction, the most desperate ones: those in which bankers were less interested and for which the last-resort effort was left to bondholders. We do not say that these were unexciting or irrelevant cases, nor that the recent interest in bondholders' committees (and in how they acted) is entirely misplaced. But we do argue that a good deal of filtering occurred upstream, so that a focus on bondholders suffers from selection bias. We therefore doubt that such a focus is an adequate starting point for studying the global financial architecture of the period 1815-1913.

In this paper, we will study why and how prestigious underwriters (here, Rothschilds and Barings) found themselves helping out investors. We will argue that they did it in different ways an that there was product differentiation within prestige. Rothschilds specialized in the safest financial instruments and did a lot of monitoring and crisis lending in order to avoid default. Barings, on the other hand, engaged in riskier deals (witness the Barings crisis!). They were involved, post-default, in debt restructuring and/or credit restoration operations. In other words, they acted as a collection agency for other bankers' deals: coming to the rescue of borrowers' honor (after borrowing countries had failed), which they sought to restore in order to shine their own shield.

In summary, this perspective implies a nearly complete reversal of recent research trends. It has been argued elsewhere that bondholders created value by creating missing institutions of collective action to control market access (in essence, taking a stake in the underwriting process); however, we shall argue that prestigious underwriters created value by handling the enforcement of delinquent debts and relying on a market power that was already there (in essence, exercising the kind of market access control that has been traditionally associated with bondholders).

The balance of the paper is organized as follows. Section I starts with recent work on bondholders' committees and moves on to show that such discussion, interesting as it is, neglects one critical fact: that the uncertainty of securities performance (the spread between expected and actual performance)

\footnotetext{
${ }^{5}$ The Economist (20 November 1897, p. 1624).
} 
was influenced by the identity of the underwriter who originated the deal. Section II articulates predictions from relationship banking theory and finds empirical support for them: borrowers that seldom switched underwriters were perceived as less risky. We also show that the market share of prestigious banks increased during downturns. Section III takes a closer look at the role of relationship banking in dealing with payment crises. We argue that the help provided to the borrowing country was customized to maximize underwriter's prestige. A case study (involving Brazil and the House of Rothschilds) enables us to show that "international lending of last resort" took place at penalty rates, indicating that prestigious banks were not philanthropists. Section IV analyzes the historical record of the House of Barings. We explain how and why prestige was used to deal with defaulting countries whose loans had been originated by other (ordinary) banks: prestige, in its Barings variant, ensured the credibility of the underwriter's role as a collection agency. Section $\mathrm{V}$ completes the story: it provides a formal test of the comparative strength of bankers and bondholders' associations by comparing the market's judgment on their respective involvement. The results show that bondholders lacked credibility. Section VI concludes.

\section{Underwriters' Prestige and Bondholders' Value: Evidence from the Mid-19 ${ }^{\text {th }}$ Century}

\section{A. Bondholders and trouble}

Since the Latin American debt crisis in the early 1980s, management of international default is conventionally acknowledged as a critical facet of the operation of the international financial system. Absent international forms of enforcement, improvement in the outcomes of bargaining may be possible through reliance on market institutions, such as bondholders' committees or collective action clauses (CACs) that limit obstruction by minority bondholders and foster creditor cooperation. ${ }^{6}$ In addressing this possibility, analysts needed to understand how earlier regimes characterized by global financial integration managed this unpleasant feature of international lending. The result was increased and widespread interest in the London-based bondholders' committee created in 1868 and known as the Corporation of Foreign Bondholders (CFB), which was widely discussed in global think tanks and international financial institutions.

Building on early work of Ronald (1935), Borchard (1951), and Wynne (1951) and on material contained in CFB Annual Reports, the recent literature was initiated by the papers of Eichengreen and Portes $(1986,1989)$. These authors argue that the superior organization of the British CFB compared with its U.S. counterpart (the American Foreign Bondholders Protective Council) explains the superior recovery rates of British bondholders. More recently, Wright (2004) provides theoretical arguments suggesting that the CFB served to enforce collective behavior among creditors by "naming and

\footnotetext{
${ }^{6}$ On default and the political economy of bargaining, see Aggarwal (1989, 1996). On bondholder committees, see Eichengreen and Portes $(1986,1989)$ as well as the other cited works in this section. On CACs, see Eichengreen, Kletzer, and Mody (2003).
} 
shaming" members who defected from credit embargoes and lent to defaulters. ${ }^{7}$ Mauro, Sussman, and Yafeh $(2006$, pp. 128-129, 162) argue that the CFB sought to protect the interest of its members by providing them with information about the borrowing countries and by fostering coordination among creditors. Esteves (2007) studies the performance of CFB-sponsored settlements and draws favorable conclusions.

\section{B. The trouble with bondholders}

All this is fair enough; indeed, it is what the Corporation's reports tried to persuade people it was actually doing. However, it is unanimously acknowledged by the writers already cited that the empirical basis for making such inferences is fragile. The reason (as we discuss later) is that counterfactual measures of the effect of bondholders' committees are not easy to construct. In addition, theoretical insight suggests that the case for bondholders monitoring is not airtight. If there is nothing else for bondholders to rely upon (as is much the case today), then they'd better be organized. At the very least, few would dispute that a bit of cooperation on the creditors' end can do no harm. The point is that the $19^{\text {th }}$-century world was not the vacuum suggested by modern discussions; rather, it was a world peopled with intermediaries (the underwriters) who took to heart the responsibility of enforcing some measure of gate-keeping (Flandreau et al. 2010).

As a result, much happened before any matter was put in the hands of bondholders. Just as today's IMF usually makes a last-ditch effort to shore up a failing country, intermediaries in the past were involved at the early stages of any crisis. In fact, intermediaries were often involved even before the crisis occurred - that is, when the security was structured and sold. And they did not walk away as the security aged. Lending certainly did not occur in an environment dominated by conflicts of interest, as usually portrayed by advocates of the importance of bondholders' committees (Flandreau and Flores 2009). Instead, foreign lending occurred in the well-organized, hierarchical international bond markets, where huge piles of capital served to collateralize government debt. Those who owned the capital had a special role to play because this capital was the security on which foreign debt markets were based.

To see intuitively how the system worked, consider a world in which there are two types of investors (informed and uninformed) and two types of governments (good and bad). Ordinary investors cannot tell a borrowing government's type but informed intermediaries, the underwriting banks, can. However, intermediaries have incentives to cheat investors because their fees are thereby increased; yet investors understand that. In this context, sovereign debt may emerge as bankers are sorted into a "pyramid": prestigious bankers have monopoly power and specialize in high-grade securities, while ordinary underwriters are competitive and deal with low-grade bonds. Flandreau and Flores (2009) show that Rothschilds was the leader during the 1820s; it surpassed all other banking houses in terms of market share, capital stock, and performance of issues. Prestige was used as

\footnotetext{
${ }^{7}$ Wright (2004) also claims that the CFB's creation can be traced to recent violation of a creditors' embargo and argues that the CFB was effective in deterring further violations.
} 
collateral for successful origination and distribution of high-quality government securities. That prestigious Rothschilds securities outperformed the rest underscores the role of prestige in supporting the rise of early $19^{\text {th }}$-century government bond markets. Monopoly power by prestigious houses was the endogenous solution to a market problem, and it provided incentives for truthful revelation: a large market share ensured that misrepresentation was a suboptimal policy. For these banking houses, their foundation of sovereign debt was a barrier to entry that kept lesser houses - and conflicts of interestat bay. ${ }^{8}$

Now, a straightforward corollary from the preceding analytics is that ex ante monitoring should have had a counterpart in ex post efforts to make ends meet. A banker who is concerned about the performance of securities he has originated should not walk away from the deals when headwinds are faced. Some evidence of this resilience is reported in Flandreau and Flores (2009), where we find that the volatility of non-Rothschilds bond prices was not transmitted to Rothschilds bond prices; this indicates (and anecdotal evidence also suggests) that Rothschilds intervened to support its securities and that markets expected such interventions. Fighting contagion is one aspect of crisis management At a broader level, we ought to see prestigious banks making sure that value is delivered and acting as delegated troubleshooters in charge of dealing with crises and restructuring ailing countries.

\section{Trouble Free: Evidence}

This "holy triangle" of sovereign debt management (the happy combination of countries' performance, bondholders' value, and underwriter's prestige) is implied by early business historians' accounts of leading firms. Hidy (1949, p. 477) claims that the House of Barings felt "it assumed responsibility to both buyer and seller when it publicly marketed the securities of any government or corporation. That responsibility involved not only the protection of the borrower's credit but also the investment of the client and the reputation of the marketer [i.e., Barings]." Reflecting on this, Hall (1963, p. 71) adds: "it is not unlikely that a similar pattern of operating was evolved by the other leading houses." Gille's (1965) account of the operations of the House of Rothschilds during the $19^{\text {th }}$ century reads like a catalog of quotes suggesting that prestigious underwriters displayed constant concern over clients and customers alike. The reputation of the intermediary rested on successful cooperation.

To what extent did prestigious banks deliver reliable outcomes throughout the $19^{\text {th }}$ century? Business historians have assumed they did, but none have actually checked. In addressing the question, this paper combines information on expected and realized returns. For a given bank, if realized returns tend to equal expected ones (i.e., if ex post performance resembles the promises made

\footnotetext{
${ }^{8}$ Previous research suggests Flandreau and Flores (2009) interpretation of the 1820s applies throughout the 19th century - a natural outcome given that market share supported credibility, which in turn protected market share and so generated persistence. Rothschilds retained its leadership in London sovereign issues until World War I, with Barings (the other prestigious house) never too far behind. Moreover, Rothschilds (the most prestigious firms with the greatest market share) had the lowest loan casualty rates during the major debt crises of the $1870 \mathrm{~s}$ and 1890s (Flandreau et al. 2010). Flandreau and Flores (2010) find that switching from a prestigious to a nonprestigious underwriter entailed a 300-basis-point increase in bond spreads.
} 
ex ante) then the underwriter is reliable. We may thus construct a scatter plot of realized returns as a function of ex ante yields. Expected returns are computed using information on issue prices and loan characteristics (and are estimated as the yield to maturity, YTM). Realized returns are measured by computing the actual performance of a security over its lifetime, which entails collecting material on the security's history (realized rates of returns are painstakingly estimated as the internal rates of return, IRR). We have gathered the required evidence to document the performance of individual bonds whose sales were recorded during the mid- $19^{\text {th }}$-century boom-bust cycle that finally collapsed in the 1870s (Jenks 1927; Landes 1958; Suzuki 1994). We look at the universe of bond issues during the period 1850-1873 and, for each bond, trace its payment record up to $1878 .{ }^{9}$

Previous studies (e.g., Lindert and Morton 1989) have examined the debt record and have famously suggested that ex post returns were not so bad in the past and that this implied that some form of market discipline or relevant pricing was at work. However, this paper is the first to perform an empirical test of the matter by conditioning returns on underwriters' identity. This approach (which represents an important departure from traditional portfolio choice theory emphasis on risk and returns of individual securities) highlights the crucial role of signaling by intermediaries. ${ }^{10}$

The outcome of our test is shown in Figure 1. We represent expected returns on the $x$-axis and realized returns on the $y$-axis. The diagonal line, which we call the reliability line, plots where expected and realized returns equal each other. Because the horizon we consider is not exactly comparable across securities (we use a fixed horizon even though securities were issued at varied dates) and because of some minute computational issues, discrepancies from the $45^{\circ}$ line may be observed even for well-performing securities - but the point is that these discrepancies are small. Observations below the confidence line mean that expectations were not met: this is the "disappointment area". To make the chart legible, we have limited losses to a compounded annual $11 \%$ (the actual numbers, which can be much lower, are available from the authors). Note that the Rothschilds deals are marked with squares and the Barings deals with lozenges; triangles mark outcomes for the House of Bischoffsheim-Goldschmidt. This latter firm was chosen because, according to a subsequent parliamentary panel, it was the villain in this boom-bust cycle. ${ }^{11}$ All other bankers' deals are marked with dots.

\section{[[ INSERT Figure 1 about Here]]}

\footnotetext{
${ }^{9}$ The choice of a time horizon is arbitrary. An alternative is to compute the return over the entire life span of the securities. However, this is also arbitrary because the procedure would benefit bonds that were repaid before a major international shock. One advantage of picking the 1877 horizon is that it is subsequent to the series of defaults in the 1870s. A longer horizon was chosen for Russia because the country was then at war. Despite experimenting with different dates, we find that our basic conclusions do not change.

${ }^{10}$ Spence (1973) is the seminal paper on the importance of signals in economics.

${ }^{11}$ See Select Committee (1875), Jenks (1927), and Suzuki (1994).
} 
The figure strongly suggests that, for prestigious houses, expected and realized returns closely matched one another. The most impeccable record was that of the House of Rothschilds. ${ }^{12}$ Barings's record was quite clean, but they had one loan to Venezuela that turned sour. We see by contrast the disastrous record of Bischoffsheim-Goldschmidt. Moving to numbers, the correlation between ex ante and ex post returns was highest for Rothschilds (above 0.7). For the rest it was negative (about -0.5 ). In other words, the prestige of a "name brand" was a source of reduction in uncertainty-a valuable service for risk-averse, information-poor investors. Reflecting this was an exchange between Sir Henry James (MP) and Nathaniel de Rothschild during the hearings of the Select Committee that convened in 1875 to examine the foreign bond debacle of the 1870s. Sir Henry asked, half in jest: "But you have had experience, however, only with good loans?" Nathaniel replied: "Only in good loans, I am happy to say."13 The head of the House of Bischoffsheim-Goldschmidt, understandably, did not dare to show up during the same interviews. He prudently sent instead a physician's certificate.

The conclusion is that certain bonds did not need the intervention of bondholders in order to deliver value. The other ones were understood by the public to be dangerous because household brands were not attached to them. While they still may have been priced in an over-optimistic way (the $8 \%$ to $12 \%$ yields at issue of Bischoffsheim-Goldschmidt securities failed to compensate investors for subsequent losses) their high yields imply they were definitely not perceived to be investments for widows and little children. And since Rothschilds and Barings had a leading market share, the conclusion must be that a large part of the management and trouble shooting of the international financial system of the time was taken care of by prestigious banks and not by bondholders' committees. Therefore, popular arguments about intermediaries' free riding behavior deserve a harder look.

\section{Relationship Banking: Theory and Evidence}

The next item on the agenda is to determine whether prestigious bankers' unusual results were achieved through making the right choices or through proper monitoring. Flandreau and Flores (2009) emphasize Rothschilds's ability to cherry-pick. Yet even the world's best cherry-picking cannot rule out accidents. What did prestigious bank do when inopportune events knocked on the door? We address this question in this section. For this purpose, we rely on insights from an expanding body of theoretical literature that studies the condition under which "relationship banking" emerges and replaces (or complements) the action of creditors. The main insight of this theory is that banks can serve well as delegated monitors for shareholders and creditors and, in effect, deliver value. Among variants of this intuition, economists emphasize three factors: (1) main banks have advantages in gathering information about clients through economies of scale (the cost of information gathering declines with repeated transactions); (2) there are economies of scope in that banks utilize the

\footnotetext{
${ }^{12}$ This is consistent with evidence in Flandreau and Flores (2009) for the 1820s and Flandreau et al. (2010) for other periods.

${ }^{13}$ Select Committee (1875, p. 270).
} 
information obtained through provision of other services; and (3) repeated transactions across services may enable banks to address problems arising from information asymmetries and incomplete contracting.

The relevance of these arguments for the $19^{\text {th }}$-century international organization is obvious. Theoreticians have often stressed the importance of incomplete contracting in sovereign debt. ${ }^{14}$ In $19^{\text {th }}$-century bond markets, relationship banking emerged to address asymmetries of information and the attendant limitations in contracting. But repeated interaction also meant that prestigious banks ended up knowing more about "their" countries. Another aspect of this mechanism was the existence of economies of scope, since experience with some countries enhanced the monitor's ability to make comparisons and inferences across customers. Still another positive externality arose from prestigious banks' incentives to punish one country in order to protect their present and future ability to certify other countries. ${ }^{15}$ Finally, the relationship banking theory suggests that the main bank does not act solely through signaling but also through control. The main bank has a capacity to deliver value by enforcing proper policies and creating incentives for organizational reform when needed. ${ }^{16}$ In the language of public finance, the equivalent of firm reorganization is fiscal restructuring. Thus our metaphor implies that, during the $19^{\text {th }}$ century, the main banks had decisive influence on macroeconomic policies. Of course, this is fully consistent with earlier popular and more academic historical accounts of the House of Rothschilds, each of which provides abundant anecdotal evidence of the advisory role this prestigious bank played for governments (Reeves 1887; Gille 1965, 1967; Bouvier 1992).

\section{A. Spreads and Turnover}

One way to get straight at the heart of the relationship banking analogy is to explore the link between borrowing countries' spreads and their turnover with underwriters. We can think of it as a relation between the strength of the banker-country bond and the country's market-perceived risk. We expect that countries that switched bankers less often were perceived as less risky. This prediction arises because countries that switched rarely remained attached to good bankers (a country being faithful to a bad banker is by definition unlikely to occur, which the data confirm) and because good bankers (to maintain their reputation as good) helped these countries bridge over financial trouble to the extent

\footnotetext{
${ }^{14}$ See Bulow and Rogoff (1989) for a classic statement that emphasizes how lenders' competition leads to the breakdown of sovereign debt.

${ }^{15}$ This shows that the conventional perspective on the House of Rothschilds-according to which its ascendancy proceeded from superior informational capacities (the apocryphal pigeons story) - may actually be reversed: information arose because Rothschilds was able to certify, not the other way around. Proponents of the view that information was exogenous to Rothschilds's prestige include Gille $(1965,1967)$ and, more recently, Liedtke (2008).

${ }^{16}$ Hoshi, Kashyap, and Sharfstein (1990), Sharpe (1990), Gertner and Scharfstein (1991), Petersen and Rajan (1994), Boot (2000), Boot and Thakor (2000), Lehmann and Neuberger (2001). Rajan (1992) addresses the capture problem. See Flandreau (2003a) for a discussion of relationship banking in $19^{\text {th }}$-century international financial architecture.
} 
that countries were illiquid rather than insolvent. Such countries were therefore perceived by investors as being less risky. As a first approximation, then, we expect a positive relation between turnover (a measure of stability in banking relations) and average yield spreads at issue (a measure of sovereign risk as it is priced on the date of issue). ${ }^{17}$

The data used for this exercise covers 1877-1913. There are two reasons for this choice. First, this fairly extended time period provides enough market access events for individual countries to enable us to compute meaningful estimates. Second, examining a period later than the mid- $19^{\text {th }}$ century (used in Section I) is useful for confirming that our model has broad validity throughout the entire $19^{\text {th }}$ century. ${ }^{18}$ We define turnover as the probability that two subsequent loans to the same country are issued by different underwriters; we compute it as the sum of underwriter switches divided by the number of issues. In percentages, the value ranges between $0 \%$ (no change) and 100\% (systematic change). ${ }^{19}$ We excluded from the data set all countries for which fewer than three loans were made, as in such cases the volatility in the estimation of turnover is spurious. Figure 2 shows a significant and large positive relation. Countries faithful to their banker had lower interest rates, ceteris paribus. Other countries were like hot potatoes that ordinary bankers passed to one another-and to the public, who understood the risks involved. ${ }^{20}$ The empirical evidence fits the notion that privileged banking relations were closely associated with expected cooperation with bondholders. ${ }^{21}$

\section{[[ INSERT Figure 2 about Here]]}

\section{B. Role of Prestige in Debt Cycles}

Another way to consider the effects of relationship banking is by looking at boom-bust cycles. As already stated, relationship banking is expected to provide resources to deal with payment crises. An implication of our view is that prestigious banks' support becomes particularly valuable during crises. In times of euphoria, the relative value of aristocratic financiers' signal weakened owing to reduced risk aversion, but their seal of approval became critical during busts. When a crisis hit, investors suddenly became leery of risking further capital in the foreign debt market; at the same time, liquidations created havoc in governments' ability to borrow (those who were caught short of funds faced serious problems). We therefore make the following prediction: the market share of prestigious

\footnotetext{
${ }^{17}$ Cairncross (1953) makes a similar claim in explaining why Argentina's yields were higher than Brazil's. Note that a finer implication of our analysis is that countries with a better track record are more able to switch underwriters. In other words, a greater ability to self-certify (as obtains in stable environments) should increase turnover. We neglect this property in this study.

${ }^{18}$ Sources for this data set are described in Flandreau et al. (2010).

${ }^{19}$ When there are multiple underwriters, if any of the underwriters from the past issue is among the underwriters for the current issue then we do not count this as a switch.

${ }^{20}$ For a paper making related claims in a different context, see Krigman, Shaw, and Womack (2001).

${ }^{21}$ This finding may go some way toward explaining the puzzle in Tomz and Wright (2007), who find that the historical link between defaults and "bad times" is weaker than what most modern theories predict. The reason is that default has more to do with the banking relationship than with the economic environment.
} 
houses depends on boom and bust cycles. During booms, risk aversion declines, and investors are more eager to play with new and possibly dangerous instruments. Hence new underwriters have an easier time, new debts are successfully issued, and the ability of serious houses to resist the push is more limited. To the extent that the market share of prestige is determined by the prestigious underwriter's ability to address asymmetries of information, any perceived reduction in such asymmetries heralds an erosion of prestige. During the crisis, however, old lessons are relearned as bad borrowers default. Prestige is back, and good countries in trouble can still access the market through the help of their elite bank (relationship banking argument).

To test whether this hypothesized connection is supported by the data, we have identified, within our data set of sovereign debt issues during the period 1820-1900, the amount of Rothschilds and nonRothschilds issues on a year-by-year basis and then aggregated the numbers, distinguishing between boom and bust eras. ${ }^{22}$ Previous authors have identified three such cycles in the $19^{\text {th }}$ century: the early 1820s boom, which petered out in late 1825 and early 1826 (Jenks 1927; Flandreau and Flores 2009); the long boom of the years 1850-1870, which imploded in stages between 1871 and 1876 (Jenks 1927; Suzuki 1994); and finally the protracted expansion that begun in the late 1870s, stalled in 1889 , and then reversed with the Argentine default and "Barings crisis" of 1890 (Ford 1962). ${ }^{23}$

The results are shown in Figure 3, which delivers a straightforward message: Rothschilds's market share was typically smaller during periods of expansion in sovereign debt issues and then recuperated after the collapse. Matching this evidence, we note that it was actually common among prestigious banks to be particularly vocal during busts in emphasizing that investors who had bought through lesser houses (in effect, their lower rank competitors) deserved to be punished - the modern word would be "bailed in". ${ }^{24}$ Beyond the Victorian moral overtones, the prestigious bankers were stating a fact they knew quite well. Prestige was counter-cyclical and this was an outcome of game ruled by relationship banking.

\section{[[ INSERT Figure 3 about Here]]}

\section{The Theory: Tit-for-Tat}

The theory of international lending in the $19^{\text {th }}$ century is therefore enriched once we recognize that there was more to the game between borrowers and capital markets than a confrontation between rational borrowing governments and atomistic bondholders seeking safety in collective action institutions. In this section, we discuss theoretical foundations for conditionality lending by special, prestigious banks, and use a case study to illustrate the principles we articulate. The evidence surveyed

\footnotetext{
${ }^{22}$ Since there are years without loan issues, adding up numbers over eras makes results more consistent.

${ }^{23}$ The data in Stone (1999) does support the notion of a sudden stop in capital exports in 1889/1890.

${ }^{24}$ In 1828, (i.e. after the 1825-26 market reversal), Alexander Baring had publicly emphasized that bondholders were consenting adults who should pay for their "gambling losses" (Quoted in Dawson 1990, p. 193). Similarly, the exchange already mentioned with Nathaniel de Rothschild during the hearings of the 1875 Select Committee had the banker declaring about the hypothetical Khan of Khiva loan that "anybody who subscribed to that loan must know that he is subscribing to a loan which is utterly worthless" (Select Committee, p. 268).
} 
earlier points to a natural mechanism whereby these special banks were in a position to enforce adjustments as a quid pro quo for the funds they provided to countries: I shall provide you with funds, but your will undertake actions that maximize the likelihood of sustained debt service and in fine protect my own reputation. Conditionality lending, we argue, is thus an investment in the bank's own brand.

The mechanism through which adjustments could be credibly enforced rested on the costs a country - if unwilling to undertake prescribed policy actions in return for funding —-would suffer from the banker's retaliation (this is discussed more formally in Appendix A where we provide a marginal condition for cooperation). Prestigious houses valued their brand and asked for adjustments that they claimed were necessary to protect the country's credit but the real target and concern was of course the bank's own credit. Countries were thus asked to undertake some costly action. If they refused to cooperate, the banker would refuse to provide them with market access. It was not unusual for a prestigious banker to make it known that it had refused lending to a certain country. ${ }^{25}$ When this happened, the country could then turn to a lower-rank underwriter. But the lower-rank underwriter was not as prestigious and so its terms were more onerous (switching was itself viewed as indicating a possible problem). ${ }^{26}$ The country could also postpone borrowing, or else turn to domestic markets. The extent to which its money needs were urgent and its domestic capital markets were well developed thus determined its bargaining position with respect to bankers.

This required adjustment was fully credible in the hands of prestigious banking houses. Indeed, the bulk of their revenues stemmed from owning a large market share in successful loans, not from the fees garnered on individual issues. There was thus no trade-off between fees and reputation (unlike what previous authors have implied), since the failure of any loan would reverberate across the board and so impair the bank's ability to make other issues of good loans. Therefore, the greater the bank's concern over its brand, the stricter were the required policy actions. Our analysis also suggests that prestigious underwriters would not hesitate to enforce a long embargo against deviating countries, and there is evidence that this was the case. ${ }^{27}$ Quite naturally, a prestigious bank would be unwilling to lend to such countries until investors were properly compensated, since only full compensation ensured restoration of the banker's prestige. As we shall see, bankers made sure that bondholders received bonuses when they were exposed to undue excitement: sound banking had to be dull.

Thus prestigious houses were unwilling to undercut the terms of a credit embargo, because they were the ones to impose it in the first place. The reason again is that there was no point in preventing

\footnotetext{
${ }^{25}$. Prestigious bankers were often accused of "talking down" that is publicly denigrating the stocks they had refused to underwrite (Landes 1958).

${ }^{26}$ For a measurement of switching costs, see Flandreau and Flores (2010).

${ }^{27}$ There is indeed anecdotal evidence of such embargoes. Examples include Rothschilds's experience in the 1860s with Italy and Austria, both of which sought to impose a capital levy on debts marketed by the House of Rothschilds. Since the bonds were initially tax-free, this amounted to a breach of faith or partial default. After working to minimize the losses for their investors (e.g., holders of Rothschild-underwritten Austrian bonds were given a reasonably favorable conversion rate into the new, taxable securities), Rothschilds walked away from both countries (Gille 1967).
} 
investors from being duly compensated by unduly supporting the credit of an undeserving country-a bank that did so would disqualify itself as prestigious. Thus, if there was an externality then it was a positive one that arose through a kind of "competition of virtue". If the name of the game was the bank's track record, then prestige could only be secured by making sure that harsher terms be applied. The outcome squarely opposes the conventional emphasis on free-riding.

In summary, the claim we make is that, for prestigious bankers, implementing punishment meant future rents (the fees from future good loans) rather than forgone revenues (the fees from the bad loans they decided not to issue). In the language of theory, the game under consideration is one where prestigious intermediaries lend support depending on whether the country's behavior is proper (i.e., cooperative). Our theory of conditionality lending belongs to the "tit-for-tat" or "equivalent retaliation" family of games in which players can sustain a given equilibrium by inflicting adequate penalties when another player deviates (the usual reference in this literature is Axelrod 1984).

\section{Conditionality Lending and Liquidity Crises: Case Study}

A case study will now help us explore the consequences of the previous argument. Through their ability to punish countries, prestigious houses acquired leverage over macroeconomic governance. In order to show this, we must find an instance where some shock moved a bank-borrower relation off equilibrium so that we can observe the resulting adjustments. Yet the very nature of this relation is such that observable shocks are rare events (otherwise, the bank would not be prestigious). For this reason, the intriguing episode of the 1898 Brazilian "Funding Loan" is precious. At that time, a serious fiscal crisis - triggered by the mismatch between Brazil's debts, which were denominated in sterling, and its own depreciating currency - threatened to push Brazil into default. The origins of this episode are in the early 1890s, when Brazil, following the so-called Encilhamento, engaged in expansionary monetary and banking policies. ${ }^{28}$ Expansion of the money supply fueled exchange depreciation. ${ }^{29}$ In 1898, the situation came to the breaking point: had interest service been paid in sterling, it would have absorbed $62 \%$ of total government revenues. ${ }^{30}$ In May 1898 , markets were anxiously expecting a moratorium on debt repayment. ${ }^{31}$

However, Brazil was the Rothschilds country par excellence. Table 1 documents the underwriting record of Brazilian government loans between the mid- $19^{\text {th }}$ century and the Funding Loan of 1898 . And shows Rothschilds controlled $100 \%$ of the franchise. Some observers were quick to point out that Brazil's problems were indeed a test of Rothschilds's touch. For instance, when the country's situation

\footnotetext{
${ }^{28}$ Topik (1987), Triner (2000), Abreu (2006).

${ }^{29}$ On the mismatch problem during the 1890s, see Flandreau (2003a) and Flandreau and Zumer (2004). The dangers of such a mismatch were rediscovered during the Asian and Russian crises of the late 1990s.

${ }^{30}$ See Flandreau and Zumer (2004) for an estimate of this counterfactual interest service. Assessment by the international banking community put Brazil in the group of countries whose finances were shaky (see Flandreau 2003b).

31 “Brazilian Finance," Investors Monthly Manual (31 May 1898, p. 225).
} 
threatened slipping out of control in the Spring of 1898, the Investors Monthly Manual emphasized that the lesson, should default occur, may be that investing classes "should think for themselves, and not follow blindly whoever chooses to lead them, whether Rothschilds or Barings, Barnatos or Hooleys" (the latter two were famous swindlers of the time). ${ }^{32}$ Some analysts have suggested that Rothschilds faced a conflict of interest that would have led it to be too lenient with Brazil and that the reason why Rothschilds "bailed out" Brazil in 1898 reflected the bank's conflict of interest. ${ }^{33}$ In contrast, our argument implies that if Rothschilds did not handle Brazil's crisis properly (meaning not just a bailout but a proper restructuring) then the bank's ability to underwrite other countries in the future would be damaged. Therefore, any support they would give could not be a "bail out". It had to be costly for Brazil and rewarding for investors.

\section{[[ INSERT Table 1 about Here]]}

Brazil did not default; instead, a Rothschilds-sponsored debt restructuring was organized. The socalled Funding Loan was announced on 20 June 1898 when Rothschilds asked The Times to publish the correspondence of Brazil's president-elect Campos Salles, which emphasized the Brazilian government's commitment to fiscal stabilization. ${ }^{34}$ The terms of the agreement then became public. ${ }^{35}$ The Funding Loan had two sides, one macroeconomic and one financial. The macroeconomic side was summarized in the "Funding Scheme" appended to the underwriting contract. ${ }^{36}$ This scheme recognized that the source of the crisis was a mixture of monetary and fiscal problems. It was fiscal because the government could not service the debt, and it was monetary because exchange depreciation against a sterling debt had exacerbated the debt problem. Funding securities were created to pay for the debt and their floating was conitional upon monetary entrenchment: Brazil, under the supervision of trustee banks, was instructed to burn paper notes in counterpart (pari passu was the chosen wording) to the funds received. ${ }^{37}$ The monetarist rationale of the scheme is obvious: reducing

\footnotetext{
${ }^{32}$ Investors Monthly Manual (31 May 1898, p. 226). Barney Barnato, the South African "Diamond King", committed suicide in June 1897 by jumping overboard from a vessel on its way from Cape Town. Hooley, known as the "Napoleon of Finance", was a promoter of companies who went bankrupt in 1898 amid revelations of deceptive accounting practices. Of course, since the Investors Monthly Manual was itself printing macroeconomic information and making commentaries, its judgment was not disinterested.

${ }^{33} \mathrm{We}$ understand that this argument is also made in an unpublished dissertation by Leonardo Weller, but we have not seen this work. See Weller (2009).

${ }^{34}$ Campos Salles was then visiting London and was "in constant communication with his government on the subject" (The Times, 20 June 1898). Abreu (2000) suggests that Brazilian authorities did not know Rothschilds intended to publicize their correspondence.

${ }^{35}$ The Economist (30 June 1898).

${ }^{36}$ Both the contract and the signed "United States of Brazil Funding Scheme" are located in the Rothschilds Archive in London.

37 "The paper money equivalent to the Bonds issued from the $1^{\text {st }}$ of July to the $31^{\text {st }}$ of December 1898 , will be deposited [in Trust with the London and River Plate Bank, Limited, the London and Brazilian Bank, Limited, and the Brazilianische Bank für Deutschland]. The paper money deposited will either be withdrawn from circulation and destroyed, or if the Exchange is favourable, will be applied in the purchase of Bills on London [sterling exchange] in favour of Messrs. N. M. Rothschild \& Sons, to be placed to the credit of a Fund towards
} 
the money supply would boost the exchange rate and decrease the burden of interest service, enabling authorities to resume normal payment of external obligations (of course, the sterling value of the nominal debt would increase in response to the issue of additional Funding securities). This is indeed what happened: monetary contraction was followed by exchange-rate stabilization.

Brazilian historiography is uniformly critical of the dislocating effect that Rothschilds's stabilization program had on Brazil's domestic economy. Nonetheless, government fiscal balance was restored. ${ }^{38}$ This result is consistent with our view that the primary beneficiary of the funding scheme was Rothschilds's own reputation (showing they were no Barnatos), not the Brazilian economy. The conclusion becomes even more patent when we examine costing. Recall how Figure 1 and Figure 2 showed that the Rothschilds prestige depended on predictability of returns. The collapse in Brazilian bond prices that occurred before implementation of the Funding Loan dented Rothschilds's reputation for reliability, as the Investors Monthly Manual had reminded investors. The only way to restore credibility, therefore, was to find a way to increase ex post returns beyond initial promises (i.e., above the $45^{\circ}$ line). In other words, it was not enough that investors would eventually receive the full value of their expected return. Since they had been harmed by volatility and would blame Rothschilds for this, investors were owed some compensation: Brazilian securities now had to outperform initial expectations in order to ensure that the Rothschilds seal of approval would not be tarnished.

The Funding Loan effected this compensation by distributing new securities to the holders of former ones. In exchange for forbearance, holders of Brazilian debt received Funding securities at discount prices. Because the Funding Loan did not have an "issue price" and instead was distributed in exchange for coupons that investors turned in, there is no well-defined yield at issue that can be compared to other securities issues. However, we can estimate the opportunity cost by looking at the short-term performance (aka "Initial Public Offering discount") of the Funding portfolio. ${ }^{39} \mathrm{~A}$ comparison of the Funding portfolio's price in June 1898 (date of issue) with the first available quote of the Funding Loan (on 3 September 1898), a metric known in modern finance as the "run-up" that is taken as a measure of the cost of external funding, gives a mammoth increase of $37 \%{ }^{40}$ In contrast,

the future payment in Gold of the interest on the Loans etc." United States of Brazil Funding Scheme, p. 2, Rothschilds Archive, 000/401 F.

${ }^{38}$ Barroso (1936, pp. 66-67) speaks of "humiliation" and the adverse effects on the economy due to retiring papel moneda da circulaçao. Fritsch (1988) states that the deflationary monetary policy had negative effects on Brazil's economy and contributed to the banking crisis of 1900. Topik (1987, p. 38) quotes a contemporary Rio newspaper to the effect that Brazil's economic policy after the Funding Loan led to three years of complete stagnation and the unquestionable decline of industrial policy.

${ }^{39}$ By comparing the funding of securities being distributed with the holding of Brazilian debt, we can compute the short-term performance of the Funding portfolio consisting of both old debts and new Funding securities (see Appendix B for the details).

${ }^{40}$ Modern finance literature recognizes that issuers and underwriters of corporate securities now deliberately underprice their issues (see, e.g., Logue 1973; Ibbotson 1975; Miller and Reilly 1987; Carter and Manaster 1990). 
modern and historical run-ups are typically a few percentage points at most. ${ }^{41}$ Holders of earlier Rothschilds-sponsored securities received this benefit. ${ }^{42}$

Another (perhaps even more appropriate) way to address the matter is by computing the ex post performance of securities that were subjected to the Funding arrangement (see Appendix B). When doing so, we find that securities such as Brazil's 1895 5\% sterling bonds had an ex post rate of return (internal rate of return) of about $8 \%$, substantially more than the yield at issue (5.9\%). This 210-basispoint excess return over investors' expectations $(8 \%-5.9 \%)$ can be taken as a measure of the reward for trusting Rothschilds in more difficult times. In view of our earlier discussion of Rothschilds delivering reliable returns, the excess performance can be seen as a quid pro quo for investors having suffered a bout of uncertainty.

This conclusion raises two questions: why were the terms of the deal so painful (Brazil emerged from the crisis more indebted than before and had to pay extra), and why did Brazil comply? The pain inflicted to Brazil is explained in terms of the reputational implications for Rothschilds, which had no better way of signaling to the public that Rothschilds was unlike Barnatos. The excess returns (as calculated here) also served this purpose and, furthermore, reminded other countries that attempts to deviate were be costly. There is little doubt that other countries reflected upon this and that Rothschilds's proven ability to punish was a potent off-equilibrium threat. Hence Rothschilds did not have a conflict of interest: the banking house was not helping Brazil, it was delivering value.

So why did Brazilians comply? The obvious answer is that Rothschilds was in a position to make a take-it-or-leave-it offer. It priced the Funding Scheme in a way that reflected Brazil's outside option (default would have led to Brazil's banishment from Rothschilds-sponsored market access). Given that Brazil was on the verge of Bankruptcy and that bankruptcy would have force it to pay much more for loans in the future, terms could not be good for the ailing country. The resulting financial triumph (for Rothschilds) reflected Brazil's limited bargaining power.

Our theoretical characterization may finally be used as a way to provide underpinnings to later accusations of "financial imperialism" on behalf of the underwriting banks in lending centers (Hobson 1902). Indeed, conditionality lending prospers on the fertile grounds of severe information asymmetries that tend to expand during crises. Theoreticians have considered situations where informational symmetries permit lenders to exploit borrowers. This is known as the "hold-up" problem (Sharpe 1990; Rajan 1992). It arises when the delegated monitor is able to capture the firm and extract a rent. A full investigation of the problem is beyond the scope of this paper, but the phenomenon is consistent with the negative assessments of the Funding Loan that are found in Brazilian historiography.

\footnotetext{
${ }^{41}$ See the works cited in note 43 as well as the historical numbers reported in Flandreau and Flores (2009).

${ }^{42}$ Investigation of the Rothschilds Archive shows that the bank was long on Brazilian bonds and thus shared in some of the gains from the large run-up.
} 


\section{Solvency Crises: Barings in the Market for Distressed Debt}

In Hamlet, the Ghost is a critical character because his demand for revenge impels the drama's action. In our financial drama, the bondholders' concern for getting their money back plays a similar role. But it takes a prestigious bank to acknowledge some liability and become involved. Consistently with what we have argued so far, it is no surprise that prestigious houses became involved in dealing with distressed debt. There is much anecdotal evidence of both borrowers and bondholders realizing that the involvement of prestigious bank houses could create value. ${ }^{43}$

To discuss the involvement of prestigious banks in debt collection we focus now on Barings, which was "number two" in London's foreign government debt market. The available evidence establishes two types of settings in which Barings dealt with countries' debt problems. First, there were situations where Barings dealt with countries with which they had been associated and that run into trouble. The archetypal instance was the "Romero" arrangement secured by Barings from Argentina in 1893 after that country defaulted on securities that, although not underwritten by Barings, had been distributed in London through Barings offices. ${ }^{44}$ Second, and perhaps more importantly, were instances where Barings involved itself with securities that it had neither originated nor distributed. Although Barings may have borne some residual reputational liabilities for not discouraging their customers from subscribing to certain debt issues, the very fact that Barings had neither underwritten nor distributed the securities was a clear signal of its reservations. ${ }^{45}$ As early as 1822 , when Barings agreed to distribute securities of the province of Buenos Aires, it emphasized to purchasers that it was not underwriting the securities and was not recommending their purchase. Therefore, getting into the market for a defaulted bond not its own cannot be rationalized solely in terms of liability management, as in the case of the conditionality discussed in the previous sections.

We argue that the motivations for a prestigious bank entering the market for defaulted bonds were not unlike those for creating the junk bond market in the 1970s. Defaulted debt tends to have a high yield and will provide handsome returns - provided the issues eventually perform. Now suppose that

\footnotetext{
${ }^{43}$ For instance, Salvucci quotes an official in defaulted Mexico declaring, in 1829, that "We should avail ourselves of the prestige that Rothschild's name brings to reconcile ourselves with European creditors and to strengthen our own credit." Salvucci (2009, p. 109). And as reported by Jenks, CFB architect Isidor Gerstenberg offered Baron Lionel Rothschilds chairmanship of the Corporation's first meeting in 1868. Jenks (1927, p. 288) relies on a paper by de Laveleye in Moniteur des Intérêts Matériels (15 November 1868).

${ }^{44}$ For more on the Continental syndicates, see Flores (2004); for more on the Arreglo Romero arrangement of 1893, see Marichal (1989).

${ }^{45}$ Previous scholars have discussed the extent to which Barings may have had some residual liability in certain U.S. states for having contributed to the distribution of debt gone bad. Hidy (1949, p. 313) suggests that Barings was not at all exposed, whereas McGrane (1935, pp. 49, 73) implies that Barings had unloaded some American stocks on their clients and would therefore have borne some liability. It is unlikely that Barings's exposure was high, given that the bank does not appear in the 1838 Fortune's Epitome as an agent for cashing the coupon of any American state except Louisiana. Tamaki (1974, pp. 64, 66) argues that American securities were not traded in the London stock exchange but only over the counter in pools managed by merchant bankers who also distributed relevant information on bond prices. At one time Barings published a circular that, in the mid-1830s, recorded not only commodity prices and some securities (e.g.,stock of the Second Bank of the United States) but also the loans of "New York, Pennsylvania, Ohio and Alabama". Whatever liability such publication may have created, it was obviously of a lesser sort than the liability created by underwriting and distribution.
} 
some prestigious bank is able to inflict penalties to defaulters by denigrating the security. The bank will then be able, at the margin, to create incentives for renegotiating other intermediaries' countries' defaulted debt. This is because the prestigious bank is in a stronger position than are ordinary bankers to provide enforcement services. The incentives may not be perfect and there may be many failures along the way; however, for a sufficient number of these debts, the ex post return will match the ex ante (high) yield and so, on average, a portfolio consisting of Barings securities will be attractive. This, we argue, explains why Barings stepped into the speculative grade bond market.

Secondary accounts of the history of the House of Barings are replete with evidence of such involvement in other bankers' nonperforming securities. Useful material on the role of Barings in sorting out the U.S. states' debt crises during the 1840s can be found in McGrane (1935) and Hidy (1949). ${ }^{46}$ Evidence on the role of Barings in dealing with defaulted debts in Latin America throughout the $19^{\text {th }}$ century is given by Marichal (1989), Dawson (1990), Costeloe (2003), and Salvucci (2009). ${ }^{47}$ Sexton (2005) surveys the role of Barings in both Americas.

We organized a case study of Barings in the U.S. states' debt crises in the 1840s by combining information on US States defaults from English (1996) and Kim and Wallis (2005). From English (1996) we classified borrowing U.S. states as nondefaulters, temporary defaulters, partial repudiators, or total repudiators. From Kim and Wallis (2005) and CFB reports we collected additional information on duration of default and other relevant details. We then turned to Fortune's Epitome (editions of 1838 and 1856) to collect information on the "window" that different US states used to service their debt before and after the crisis. Finally, we used material from McGrane (1935) and Hidy (1949) to construct - based on the language used in these sources - a qualitative indicator of the effort Barings made to persuade defaulting states to resume their interest payments. For instance, Barings reportedly made "considerable" efforts (some public, some undercover) in Pennsylvania, but they gave "never more than half hearted support to any move" toward restoration of good faith in Mississippi. ${ }^{48}$

\section{[[ INSERT Table 2 about Here]]}

Table 2 shows that Barings's efforts were more pronounced in states that ended up paying back. Barings was heavily involved in three (Illinois, Maryland and Pennsylvania) of the four states for which there was only a temporary lapse in the coupon payment. This involvement included press campaigns, articles for hire, subsidized lobbying efforts in legislatures, and so forth. One state (Illinois) in this group was handled on a U.S.-only basis with the involvement of a New York business group, which suggests that the holdings of Illinois bonds in Europe were never large. Of the states characterized by partial or complete repudiation, Barings became seriously involved with only one

\footnotetext{
${ }^{46}$ Because U.S. states are subsovereign entities, they are excluded from Flandreau et al. (2010).

${ }^{47}$ Our firsthand knowledge of the Barings Archive in London indicates that these accounts probably cover most of the relevant material.

${ }^{48}$ Hidy (1949, p. 336).
} 
(Louisiana) and eventually managed to restore that state's credit. For the rest of the delinquent states, Barings accommodated to some degree the involvement of other bankers and interest groups (in some cases, efforts were made by the underwriters); however, the results were uniformly discouraging. Of course, we know nothing of the "objective" difficulty involved in convincing various states to resume payments beyond the evidence surviving in the archives. Even so, Table 2 is consistent with our argument about reputational spillover: when it tried to coerce defaulters into paying back, Barings was actually most interested in future business. Note that Barings was a window for many more states after the crisis than before. Later on, it would underwrite Virginia and Massachusetts. ${ }^{49}$

Latin America is another place where the intervention of Barings can be observed. During the 1820s, for instance, Alexander Baring was asked twice (in 1826 and 1829) by the Mexican government to pay the coupon on bonds that had been underwritten by Barclay, Herring and Richardson. Baring accepted the first time but declined agency the second time because his conditions had not been met. The language used is consistent with the retaliatory game conducive to conditionality lending (discussed previously): "I cannot consent", Baring said, "to risk my name when I see no positive indication of the actual fulfillment of the promises and pledges which would be given through my intervention as agent of the government. ${ }^{" 50}$ Barings played a prominent role again in 1862, and in 1864 it resumed its role as Mexican agent in London. ${ }^{51}$ Barings also acted in Venezuela, proposing an arrangement for the second Venezuelan default of 1847, and in Chile, where in 1840 it intervened in the arrangement of Chile's default on an 1826 loan. ${ }^{52}$ The view that Barings was "Argentina's banker" has been proven wrong, since many other bankers originated Argentine government debt (In this sense, the link between Argentina and Barings was not the same as the link between Brazil and Rothschilds). But it is fair to say that Barings was Argentina's trouble-shooter, since it was involved in fixing more than one of the country's crises. ${ }^{53}$ We thus conclude that Barings' brand, aside Rothschilds, served differentiated purpose of finding values where there were more risk involved and certifying more dangerous countries. This "market specialization" cannot be entirely foreign to the shock the Bating received from a spillover of the Argentibe default of 1890, causing the

\footnotetext{
${ }^{49}$ See Hidy (1949, p. 311) for a similar inference: “Although the name of Baring Brothers and Company had never been publicly associated with the loans from Illinois, Indiana, Mississippi, or Pennsylvania, any improvement in the credit of those states would redound indirectly to the good name of those with which the House of Baring did have intimate connections. The reputation of Louisiana, South Carolina, Maryland, and Massachussetts, and of the Merchants Exchange, with which the name of Baring Brothers \& Cy had been publicly connected, would be expected to improve as a result of the investors associating them with those States of rejuvenated credit."

${ }^{50}$ Alexander Baring, June 1829, quoted in Costeloe (2003, p. 164). In February 1825, speaking before the House of Commons, Baring warned of the danger that the Latin American debt mania of the early 1820s was interfering with "legitimate loan-making" (Hidy 1949, p. 67). Baring emphasized that bondholders were consenting adults who should not expect governments to insure their "gambling losses". He saw wisdom and benefit in a market crash that would restore judgment; see Dawson (1990, p. 193).

51 "Baring Accepts to Represent Bondholders," ING Barings Archive, 204326. See also Costeloe (2003, p. 85).

${ }^{52}$ Dawson (1990, pp. 199, 207).

${ }^{53}$ Ferns (1952, p. 242).
} 
bank to go bust, and the Bank of England to reconstruct it, so that it could be reinvented and floated again, with benefit for the City.

A question still pending is the reason for the existence of two different uses of prestige, Barings's and Rothschilds's. Although additional research is needed to provide a full explanation, we can advance some tentative hypotheses here. As we have seen, the Rothschilds imprimatur was about reliability of returns (i.e., minimizing the spread between ex ante and ex post returns) so that investors could reasonably expect to know how much they would profit. As the case of Brazil demonstrates, in the rare instance when problems occurred, Rothschilds provided extra returns to compensate investors for the rough ride. In contrast, Barings's commitment is best understood as minimizing variance in the performance of the portfolio of securities with which they were involved, not about the performance of individual securities. Some deals could fall through (they would be located below the $45^{\circ}$ line), but on average the portfolio would be successful.

Could each bank compete in each other's domain? In other words, could Rothschilds undertake riskier deals? In theory, nothing prevents one brand from operating in two markets -- provided that proper instruments are available to differentiate the two types of deals. Yet nothing like that existed. Unless Rothschilds found a way to send clear signals regarding the group of deal in which they were entering would have invariably led investors to wonder ex post whether the deal failed because Rothschilds was imitating Barings, or because they had made some miscalculation.

Given this, engaging in both lines of business at once would have inevitably created conflicts of interests. One way to understand this is to think of the differentiation between Barings and Rothschilds in terms of the familiar opposition between solvency and liquidity. As the previous discussion has shown, the types of crisis management that the two leading banks got involved into corresponded respectively to liquidity (Rothschilds) or solvency (Barings) problems. Because such problems are distinct and call for distinct solutions, it may therefore seem quite natural to think that the $19^{\text {th }}$ century London market for foreign debt somehow found a way to differentiate among them.

For this reason, and given (as argued by Flandreau and Flores 2009) that Rothschilds had deliberately taken a lead in the market for precise predictions, Barings probably had no other alternative than to specialize in riskier instruments if it wanted to claw back its way into the market for foreign government debt. The natural tendency of reputation to persist as its owner seeks to protect accruing rents may have sealed Barings's fate, just like it did for Rothschilds. Rothschilds ended up in prime debt, Barings in "top subprime". This shadow has extended until today. We were struck by a remark from an old hand in the trade who was in charge of granting archive research authorization for Hambros, a merchant bank. As we traded jikes about various banks, he exclaimed as if he spoke the obvious: "Oh, but Barings were always more sanguine!",54

\footnotetext{
${ }^{54}$ Interview with the authors.
} 


\section{Closing the Loop: Bondholders versus Bond Sellers}

We shall now compare in a more systematic fashion the effect of bankers and bondholders' committees on performance. Earlier assessments have sought to relate the creation of certain structures (e.g., the Corporation of Foreign Bondholders) on recovery rates, and previous studies have compared the pre-CFB experience with the CFB experience. The period before 1868 is characterized by fairly long time intervals before countries accepted settlements. Marichal (1989, p. 60) reports on the length of debt renegotiation periods for Latin American countries after their defaults in the 1820s, finding that they "generally lasted between fifteen and thirty years." Suter (1992, p. 91) consults a variety of sources in examining the default record of a number of loans issued between 1821 and $1875 .{ }^{55}$ The average lengths of default are 14 years for the period 1821-1870, 6.3 years for 1871-1925, and 10.1 years for 1926-1975 (the gross average default length for 1821-1975 was 9.2). Some authors have seen these and similarly derived numbers as evidencing a positive effect of the CFB's creation in $1868 .^{56}$

Likewise, we may compare the duration of default when prestigious banks were and were not involved. For instance, a simple back-of-the-envelope calculation of the average time elapsed before an agreement was reached with bondholders for a debt restructuring after the 1820s defaults gives an average of 16 years for Barings protégés against 30 years for other Latin American countries. Thus, Barings-supported deals are at the short end of Marichal's range and the rest are at the long end. However, such exercises, regardless of the care taken, are rife with methodological challenges especially as regards comparing time series evidence. That is, such calculations presuppose that we can compare the nature of defaults across time periods-yet the timing of the trade cycle probably affected countries' willingness to cooperate with bondholders. ${ }^{57}$ An additional complication is that, given the long life of bonds, countries that had defaulted once tended to default again after the securities had been reconstructed. Because various market participants were involved at various stages, it is exceedingly difficult to provide a convincing explanation that relates settlements, performance, and intermediaries. An exhaustive archival search (to the extent that the material has survived) might provide some insight and help construct high-quality indicators, but the results would hardly be falsifiable. Moreover, we have shown that prestigious bankers provided the incentive and means for countries not to default, so such measurements would be biased even in this best-case scenario. The measurements would not take into account all the problems that did not ultimately result in default.

\footnotetext{
${ }^{55}$ His computations are based on Suter (1992), who gives as sources The Economist and the publications of bondholders' associations in England, France, and Belgium.

${ }_{57}^{56}$ A recent study along these lines is Esteves (2007).

${ }^{57}$. For instance, we observe that a substantial number of the 1820s defaults that Barings had not yet fixed were finally sorted out in the 1850s (hence our 30-year estimate), a period when global trade was booming, enabling merchant banks which were involved in both trade finance and bond underwriting to use whatever levegare they could muster to encourage debtors to settle. In a distinct, but related vein, Vizcarra (2006) argues that merchant bankers could use trade as a collateral for government debt.
} 
Here we deal with this challenge by providing a novel approach to the problem of determining who - the CFB or the bankers - had the most signaling power. Specifically: rather than comparing recovery rates, we look at market reaction to the announced involvement of either of the two parties with a stake in recovery. First, we ask whether creation of the CFB had any effect on the price of more speculative debt. Had investors believed the CFB would increase the likelihood of their receiving higher future returns, then the price of riskier countries' securities should have been driven upward. This is especially so because the CFB had not been anticipated but gained lots of visibility when it was set up in November $1868 .^{58}$

We selected three "typical" delinquent countries (Egypt, Columbia, and Venezuela) for which reasonably reliable price series are available. We then examined the reaction of their bond prices to the November 1868 announcement. Despite the attempts of promoters, the CFB's first meeting did not formally involve prestigious bankers. Looking at bond prices for high-yield borrowers around the date on which the CFB was created is thus a "pure" test of the CFB's own credibility. ${ }^{59}$ The results are plotted in Figure 4a, b and c. As the graphs indicate, the CFB's creation made no impression on the markets. This important result has apparently been missed or overlooked in previous research.

\section{[[ INSERT Figure 4 about Here]] [[ INSERT Figure 5 about Here]]}

Next, we selected a number of episodes during which (i) bondholders acted on their own, (ii) bondholders acted in conjunction with prestigious bankers, or (iii) prestigious bankers acted on their own. Case (i) is illustrated by the record of two of the countries targeted by the CFB some time after its creation (Figure 4.a and c): Venezuela (June 1869, when a CFB-mandated commission went to Venezuela to deal with default) and Egypt (in April 1870, when bondholders tried to activate a clause of a 1868 loan with the Imperial Ottoman Bank that precluded new issues after Egypt entered into discussions with Bischoffsheim for a new issue). Case (ii) is illustrated by Columbia (Figure 4.b). On 17 May 1870, The Times mentioned that a meeting of Columbian bondholders had been convened by the CFB and that resolutions for action were adopted. It was further announced that the action (unlike similar events for Venezuela and Egypt) would be conducted "in conjunction with Messrs. Baring" (emphasis added). ${ }^{60}$

\footnotetext{
${ }^{58}$ On the CFB as a surprise, see Jenks (1927) and Platt (1968). Our search (under such headings as "bondholders") through indexes for the British press of previous years did not discover any mention of the project. When the first meeting took place, however, it received much publicity and was amply covered by the British and Continental newspapers.

${ }^{59}$ The CFB was created on 12 November 1868, if we are to believe the Daily Telegraph (13 November 1868), or on 11 November, according to The Economist (14 November 1868), which mentions a meeting on "Wednesday", and to Wynne and Borchard (1933).

${ }^{60}$ The Times went on to state that "thanks were at the same time given to Messrs. Baring for the interest they have invariably taken in the affairs of the holders of the New Granada [Colombia's predecessor state] bonds"
} 
Finally, case (iii) is illustrated by one episode in which Barings acted on its own (Figure 5, which shows yields on Mexican debt, rather than bond prices). To avoid giving bankers an unfair advantage (bondholders were untested in 1868, but Barings had been around for some time), we picked an episode from the mid-1820s - a time when Barings was still new to the Latin American debt game. In February 1826, Mexican authorities with struggling finances, had lost their London window when the house of Barclay, Herring and Richardson (underwriter and distributor for Mexico) collapsed. They looked for someone to take care of the coupon, and Barings accepted in September 1826. ${ }^{61}$ Barings sought to use their position to encourage Mexico to make adjustments and even advanced funds for the payment of the coupon. ${ }^{62}$ However, Barings soon decided it was not satisfied with the situation and so, between late August and September 1827, agency was transferred to an ordinary house. ${ }^{63}$ Mexico then defaulted on 1 October 1827.

We already saw that the creation of the CFB left market unimpressed. Likewise, we see that when the CFB announced action, markets did not react (Figure 4.a and c). However, when the CFB could boast the support of Barings, there was a noticeable upward movement in prices (Figure 4.b). We therefore conclude that the CFB's ability to inflict punishment was credible only when backed by a prestigious house. Finally, Figure 5 shows that markets reacted strongly to two key events by definition unrelated to the CFB: (1) news that Barings was assuming agency in September 1826 (good news for yields, which went down); and (2) news that Barings was surrendering agency in August/September 1827 (bad news for yields, which went back up) ${ }^{64}$ Of particular interest is that the actual default (announced 1 October 1827) had less of an effect than losing the Barings connection August/September $1827 .^{65}$ The implication is straightforward. The ability of prestigious banks to drive bond prices was enormous and bondholders were, in comparison, as the Ghost in Hamlet: able to haunt but not to act.

\section{Conclusion}

This paper has provided what we hope is a more complete sketch of $19^{\text {th }}$-century global financial architecture. Our account is at odds with recent macroeconomic history research on the record of foreign debt and its focus on country characteristics and the interaction with bondholders. On the other hand, our new approach does share much insight with recent financial economics emphasis on relationship banking. It is also related to earlier business historians' emphasis on prestige. Yet our view differs from these scholars' accounts in (1) organizing a more systematic argument about why

and emphasized that bondholders were in "confidence in the good faith and favourable disposition of that Government [Colombia]" (The Times, 17 May 1870).

${ }^{61}$ Costeloe (2003), Dawson (1990), Ziegler (1988, pp. 105-106).

${ }^{62}$ The March 1827 coupon was paid "courtesy of Baring Brothers" (Dawson 1990, p. 147).

${ }^{63}$ Reid, Irving, a "second rank" house according to Hidy (1941).

${ }^{64}$ Dawson (1990, pp. 128, 147) and Hidy $(1949$, p. 66) claim that the announcement of the transfer of agency to Reid, Irving "precipitated a heavy selling wave". See also Dawson (1990, pp. 147, 148), Hidy (1949, p. 66), and Costeloe (2003).

${ }^{65}$ April and July 1827, when the coupon was not paid by Mexico, are not reported but are easy to locate. 
prestige was so important and (2) providing data to illustrate the effects of prestige and (3) identifying degrees of prestige as well as different ways of using prestige.

Rothschilds reigned supreme in "investment grade" bonds, while Barings provided the backbone of a more sanguine market and became akin to a subprime debt collection agency. Both firms' ownership of quality signals put them in a position to implement conditionality lending and to demand adjustments. This power also rendered them dependent on making ends meet because adjustments were ultimately investments in their own brands. They had "skin in the game" (their reputation was at stake) and this played a disciplining role that cast doubt on earlier claims that free riding was a serious obstacle to sound underwriting.

Finally, we examined empirically the relative powers of bankers and bondholders. We found the latter to be quite powerless. In fact, in a striking rejection of some critical assumptions of earlier research, we found that bond prices of the more exotic borrowers were unmoved by the creation in 1868 of the Corporation of Foreign Bondholders. We argued that this nonresponse indicated that the CFB was definitely not taken by contemporaries as seriously as it would be by modern research.

Perhaps the most striking aspect of the new perspective articulated here is that, although other scholars have made progress in embedding important elements of "personal exchange" into the development of broader markets based on "impersonal exchange", global finance had not yet emerged as a candidate for this kind of reconstruction. ${ }^{66}$ Perhaps scholars believed that global finance and macroeconomy was just too big to fit into such categories. However, our analysis takes us straight into a "global financial system" version of stories told by neoinstitutionalists about how some social ties facilitate enforcement of contracts. In our narrative, a market institution (prestige and concentration of market power) plays this role and lends itself also to a new explanation of why British policy makers had many powerful tools (apart from its seldom mobilized Navy) that could be relied on to "manage" the global capital market. British leaders may have rightly believed that the market would take care of itself. More probably, they knew that this market was guided by two, quite visible hands (Rothschilds and Barings) — those at the center of the debt restructuring table.

Of course, these conclusions raise one further question: Why was the CFB created when it was created? Although we have proved that bondholders did not do what previous scholars claimed they did, we must still explain why bondholders were incorporated. If bondholders' committees are not unlike the Ghost in Hamlet then future research will have to find a place for them-lest they return to haunt the literature.

\footnotetext{
${ }^{66}$ See Lamoreaux (1994) for an illustration of this phenomenon in the case of corporate and individual lending.
} 


\section{References}

Abreu, Marcelo de Paiva. 2000. Banqueiros do mundo. Nova E Monumental História Dos Rothschild Destroi Mitos E Dá Pouca Atenção Ao Brasil. O Estado de São Paulo, 3 January 2000.

Abreu, Marcelo de Paiva. 2002. Os Funding Loans Brasileiros, 1898-1931. Pesquisa e Planejamento Econômico 31: 515-540.

Abreu, Marcelo de Paiva. 2006. Brazil as a Debtor, 1824-1931. Economic History Review 59(4): 765787.

Accominotti, Olivier, Marc Flandreau, and Riad Rezzik. 2010. The Spread of Empire-Clio and the Measurement of Colonial Borrowing Costs. Economic History Review (to appear).

Aggarwal, Vinod. 1989. Interpreting the History of Mexico's External Debt Crises. In B. Eichengreen and P. Lindert (Eds.), The international debt crisis in historical perspective, pp. 140-189. Cambridge, MA: MIT Press.

Aggarwal, Vinod. 1996. Debt Games: Strategic Interaction and International Debt Rescheduling. Cambridge, U.K.: Cambridge University Press.

Axelrod, R. 1984. The Evolution of Cooperation. New York: Basic Books.

Barroso, Gustavo. 1936. Brasil, Colonia de Banqueiros: História dos Emprestimos de 1824 a 1934. Rio de Janeiro: Civilizacão Brasilera S.A.

Boot, Arnoud. 2000. Relationship Banking: What Do We Know? Journal of Financial Intermediation 9(1): 7-25.

Boot, A., and A. Thakor. 2000. Can Relationship Banking Survive Competition? Journal of Finance 55(2): 679-713.

Borchard, E. M. 1951. State Insolvency and Foreign Bondholders. New Haven, CT: Yale University Press.

Bouvier, J. 1992. Les Rothschilds. Histoire d'un capitalisme familial. Paris: Editions complexes.

Bulow, J., and K. Rogoff. 1989. A Constant Recontracting Model of Sovereign Debt. Journal of Political Economy 97(1): 155-178.

Cairncross, A. K. 1953. Home and Foreign Investment, 1870-1913: Studies in Capital Accumulation. Cambridge, U.K.: Cambridge University Press.

Carter, R. B., and S. Manaster. 1990. Initial Public Offerings and Underwriter's Reputation. Journal of Finance 45(4): 1045-1067.

Corporation of Foreign Bondholders, Annual Reports, various years.

Costeloe, M. P. 2003. Bonds and Bondholders: British Investors and Mexico's Foreign Debt, 18241888. Westport, CT: Praeger.

Daily Telegraph, various issues.

Dawson, F. G. 1990. The First Latin American Debt Crisis. The City of London and the 1822-25 Loan Bubble. Princeton, NJ: Princeton University Press. 
Diamond, Douglas. 1984. Financial Intermediation and Delegated Monitoring. Review of Economic Studies 51: 393-414.

The Economist, various issues.

Eichengreen, Barry, Kenneth Kletzer, and Ashoka Mody. 2003. Crisis Resolution: Next Steps. IMF Working Paper no. 03/196, International Monetary Fund, Washington, DC.

Eichengreen, Barry, and Richard Portes. 1986. Debt and Default in the 1930s. European Economic Review 30(3): 599-640.

Eichengreen, Barry, and Richard Portes. 1989. Setting Defaults in the Era of Bond Finance. World Bank Economic Review 3(2): 211-239.

English, William B. 1996. Understanding the Costs of Sovereign Default: American State Debts in the 1840s. American Economic Review 86(1): 259-275.

Esteves, Rui Pedro. 2007. Quis Custodiet Quem? Sovereign Debt and Bondholders Protection before 1914. Working paper, Department of Economics, Oxford University.

Fama, Eugene F. 1985. What's Different about Banks? Journal of Monetary Economics 15: 29-39.

Ferns, H. S. 1952. Beginnings of British Investment in Argentina. Economic History Review (N.S.) 4(3): 341-352.

Flandreau, M. 2003a. Crises and Punishment. Moral Hazard and the pre-1914 International Financial Architecture. In M. Flandreau (Ed.), Money Doctors. The Experience of International Financial Advice, 1850-2000. London: Routledge.

Flandreau, M. 2003b. Caveat Emptor: Coping with Sovereign Risk under the International Gold Standard, 1871-1913. In M. Flandreau, C.-L. Holtfrerich, and H. James (Eds.), The International Financial History in the Twentieth Century: System and Anarchy. Cambridge, U.K.: Cambridge University Press.

Flandreau, Marc, and Juan H. Flores. 2009. Bonds and Brands: Intermediaries and Reputation in Sovereign Debt Markets: 1820-1830. Journal of Economic History 69: 3646-3684.

Flandreau, M., and J. H. Flores. 2010. Ideologies, Industrial Organization, and International Organization: Evidence from the 19th Century. Unpublished manuscript.

Flandreau, M., J. H. Flores, N. Gaillard, and S. Nieto-Para. 2010. The End of Gatekeeping: Underwriters and the Quality of Sovereign Debt Markets, 1815-2007. NBER International Seminar on Macroeconomics 6(1): 53-92.

Flandreau, M., and F. Zumer. 2004. The Making of Global Finance. Paris: OECD.

Flores, Juan H. 2004. Lorsque le leader suit la foule: La crise Baring dans une perspective microéconomique. Dissertation, Sciences Po, Paris.

Ford, Alec. 1962. The Gold Standard 1880-1914: Britain and Argentina. Oxford, U.K.: Clarendon. Fortune's Epitome. 1838. Fortune's Epitome of the Stocks and Public Funds, by John Field, Jr. London: Sherwood, Gilvert \& Piper. 
Fortune's Epitome. 1856. Fortune's Epitome of the Stocks and Public Funds, by D. Morier Evans. London: Letts, Son \& Co.

Fritsch, Winston. 1988. External Constraints on Economic Policy in Brazil, 1889-1930. Pittsburgh, PA: University of Pittsburgh Press.

Gertner, Robert, and David Scharfstein. 1991. A Theory of Workouts and the Effects of Reorganization Law. Journal of Finance 46(4): 1189-1222.

Gille, B. 1965. Histoire de la Maison Rothschild, vol I: Des origines à 1848. Geneva: Droz.

Gille, B. 1967. Histoire de la Maison Rothschild, vol II: 1848-1870. Geneva: Droz.

Hall, A. R. 1963. The London Capital Market and Australia: 1870-1914. Canberra: Australian National University Press.

Hidy, R. W. 1941. The Organization and Functions of Anglo-American Merchant Bankers, 18151860. Journal of Economic History 1: 53-66.

Hidy, R. W. 1949. The House of Baring in American Trade and Finance: English Merchant Bankers at Work, 1763-1861. Cambridge, U.K.: Cambridge University Press.

Hobson, John A.,1902, Imperialism: A Study, New York: James Pott and Co.

Hoshi, Takeo, Anil Kashyap, and David Scharfstein. 1990. The Role of Banks in Reducing the Costs of Financial Distress in Japan. Journal of Financial Economics 27(1): 67-88.

Ibbotson, R. 1975. Price Performance of Common Stocks New Issues. Journal of Financial Economics 2: 235-272.

ING Barings Archive, London.

Investors Monthly Manual, various issues.

Jenks, L. H. 1927. The Migration of British Capital to 1875. London: Thomas Nelson.

Kim, Namsuk, and John Joseph Wallis. 2005. The Market for American State Government Bonds in Britain and the United States, 1830-1843. Economic History Review 58(4): 736-764.

Krigman, Shaw, \& Womack 2001, Why do f irms switch underwriters? Journal of Financial Economics 60, 245-84.

Lamoreaux, Naomi R. 1994. Insider Lending: Banks, Personal Connections, and Economic Development in Industrial New England. New York: Cambridge University Press.

Landes, D. 1958. Bankers and Pashas, International Finance and Economic Imperialism in Egypt. London: Heinemann.

Lehmann, Erik, and Doris Neuberger. 2001. Do Lending Relationships Matter?: Evidence from Bank Survey Data in Germany. Journal of Economic Behavior \& Organization 45(4): 339-359.

Liedtke, R. 2008. Modern Communication: The Information Network of N.M. Rothschild and Sons in Nineteenth-Century Europe. In G. D. Feldman and P. Hertner (Eds.), Finance and Modernization. London: Ashgate. 
Lindert, Peter H., and Peter J. Morton. 1989. How Sovereign Debt Has Worked. In Developing Country Debt and Economic Performance, vol. 1: The International Financial System, pp. 39-106. Chicago: NBER and University of Chicago Press.

Logue, D. 1973. On the Pricing of Unseasoned Equity Issues: 1965-1969. Journal of Financial and Quantitative Analysis 8: 91-103.

Marichal, C. 1989. A Century of Debt Crises in Latin America: From Independence to Great Depression, 1820-1930. Princeton, NJ: Princeton University Press.

Mauro, P., N. Sussman, and Y. Yafeh. 2006. Emerging Markets and Financial Globalization: Sovereign Bond Spreads in 1870-1913 and Today. Oxford, U.K.: Oxford University Press. McGrane, R. C. 1935. Foreign Bondholders and American State Debts. New York: Macmillan. Miller, R., and F. Reilly. 1987. An Examination of Mispricing, Returns, and Uncertainty for Initial Public Offerings. Financial Management 16: 33-38.

Petersen, Mitchell A., and Raghuram G. Rajan. 1994. The Benefits of Lender Relationships: Evidence from Small Business Data. Journal of Finance 49(1): 355-374.

Platt, D. C. M. 1968. Finance, Trade, and Politics in British Foreign Policy, 1815-1914. London: Clarendon.

Rajan, Raghuram. 1992. Insiders and Outsiders: The Choice between Informed and Arm Length's Debt. Journal of Finance 47(4): 1367-1400.

Reeves, John. 1887. The Rothschilds: The Financial Rulers of Nations. Chicago: McClurg.

Ronald, James H. 1935. National Organizations for the Protection of Holders of Foreign Bonds. George Washington Law Review 3(4): 411-453.

Rothschild Archive, London.

Salvucci, Richard J. 2009. Politics, Markets, and Mexico's "London Debt," 1823-1887 (Cambridge Latin American Studies, no. 93). Cambridge, U.K.: Cambridge University Press.

Select Committee. 1875. Report from the Select Committee on Loans to Foreign States. London: House of Commons.

Sexton, Jay. 2005. Finance and American Foreign Relations in the Civil War Era, 1837-1873. Oxford, U.K.: Clarendon.

Sharpe, Steven. 1990. Asymmetric Information, Bank Lending and Implicit Contracts: A Stylized Model of Customer Relationship. Journal of Finance 45(4): 1069-1087.

Spence, Michael A. 1973. Job Market Signaling. Quarterly Journal of Economics 87(3): 355-374.

Stone, Irving. 1999. The Global Export of Capital from Great Britain, 1865-1914: A Statistical Survey. New York: St. Martin's.

Suter, Christian. 1992. Debt Cycles in the World Economy: Foreign Loans, Financial Crises, and Debt Settlements. Boulder, CO: Westview.

Suzuki, Toshio. 1994. Japanese Government Loan Issues on the London Capital Market, 1870-1913. London: Athlone. 
Tamaki 1974, "The Merchant Bankers in the Early 1830s", Keio Business Review 13, pp. 59-70.

The Times (of London), various issues.

Tirole, Jean. 2002. Financial Crises, Liquidity, and the International Monetary System. Princeton, NJ: Princeton University Press.

Tomz, M., and M. Wright. 2007. Do Countries Default in Bad Times? Journal of the European Economic Association 5(2/3): 352-360.

Topik, Steve. 1987. The Political Economy of the Brazilian State, 1889-1930. Austin: University of Texas Press.

Triner, G. 2000. Banking and Economic Development: Brazil, 1889-1930. London: Palgrave.

Vizcarra, C. 2006. Guano, Credible Commitments, and State Finance in Nineteenth-Century Peru. Unpublished manuscript, University of Vermont, Burlington.

Weller, Leonardo. 2009. The Funding Loan: Why Did the Rothschild Underwrite Brazilian Bonds in 1898? Paper presented at EHS Conference (Warwick).

Wetenhall, The Course of Exchange, Various issues.

Wright, Mark L. J. 2004. Creditor Coordination and Sovereign Risk. Working paper, Stanford University, Stanford, CA.

Wynne, W. H. 1951. State Insolvency and Foreign Bondholders, vol. 2: Selected Case Histories of Governmental Bond Defaults and Debt Readjustments. New Haven, CT: Yale University Press.

Wynne, William H., and Edwin M. Borchard. 1933. Foreign Bondholders Protective Organizations. Yale Law Journal 43: 281-296.

Ziegler, Ph. 1988. The Sixth Great Power. Barings, 1762-1929. London: Collins. 


\section{Appendix A: A Condition under which Conditionality Lending Applies}

It is possible to derive a formula for the loss that prestigious banks could inflict on defaulting countries. The formula compares the cost $r_{o, t}$ of future market access (at date $t$ ) under the sponsorship of an ordinary bank (equivalent to self-certification, since ordinary banks add no value) with the cost $r_{p, t}$ of market access under the sponsorship of a prestigious bank. Assuming that the credit embargo lasts for $T$ periods and that the country intended to borrow an amount $A_{k}$ in each period of the embargo (here $k$ is the time index), we may calculate the penalty $P$ for default (where $i$ is the discount factor) as

$$
P=\sum_{k=t}^{t+T} \frac{\left(r_{o, k}-r_{p, k}\right) A_{k}}{(1+i)^{k-t}}
$$

And cooperation will apply if the benefits from defaulting are lower than the costs. Some elements of this formula are worth mentioning: First, the value obtained is a lower bound. Countries sponsored by ordinary underwriters may find themselves unable to borrow in some states of nature. Second, the only way for a country to make money on defaults is if the amount of capital appropriated (assuming the loan is never paid back) is greater than the loss entailed by future punishment. This result may obtain in countries plagued by coups (i.e., with short-term horizons) or when bankers are not prudent enough to improve monitoring by making small successive loans (resulting in a high amount of defaulted debt). Third, the figures involved in the punishment formula are substantial. Flandreau and Flores (2010) report spreads for upgrades from extreme information asymmetries of nearly 300 basis points. For the case of a perpetual bond (a good approximation of the typical loan of the time) and a $5 \%$ yield for prestigious loans (a convenient though conservative rounding-up of numbers), a 300basis-point increase in yield means a reduction in the effective capital borrowed (for any given amount of nominal debt) of about $40 \%$. The conclusion that follows from this is that prestigious bankers held a powerful tool for increasing the cost of market access for countries that refused to cooperate.

\section{Appendix B: Returns from the Funding Loan of 1898}

The Brazilian Funding loan of 1898 was a debt rescheduling whereby Brazil paid the interest on a number of external obligations (e.g., the internal gold loan of 1879) and on railway guarantees for three years (1 July 1898 through 30 June 1901) with the help of new securities. A variety of documents (kept in the Rothschilds Archive) describe the obligations of the Funding Loan, which are contained in the Funding Loan contract and the "Funding Scheme". These, along with the "General Bond", are our main sources. The General Bond and Funding Scheme stated that Brazil was to deposit (in different banks) the equivalent amount of the Funding bonds issued between 1 July and 1 December 1899 in paper money at the exchange rate of 18d. The paper money so deposited was to be withdrawn from circulation and destroyed.

The exchange of coupons worked as follows. In return for their coupons, holders would receive a receipt for the amount lodged (i.e., for the nominal value of the coupon presented). Four $£ 5$ coupons gave an investor the right to one Funding security. The Funding securities would be distributed in lieu of the coupon for three years.

The outcome of the Funding Loan received was heavily criticized by the opposition party in Brazil (Abreu 2002). In London, its terms received generally favorable coverage, although some critics complained that the CFB had not been involved in the negotiations prior to the final agreement; see for example The Economist (18 June 1898) and Freeman's Journal and Daily Commercial Advertiser (18 June 1898). Our own archival evidence shows that Rothschilds kept the CFB informed on the progress of negotiations with the Brazilian government (Letter to William Lideradle, Chairman of the Council of Foreign Bondholders, 6 June 1898, Box 000/401 F, Rothschilds Archive). In fact, many publications praised the macroeconomic and financial adjustment that Brazil had agreed to undertake and celebrated that, during this period, investors would receive "negotiable securities for the amount of their claims" and thus would be duly compensated (Daily News, 16 June 1898).

In effect, investors had little to complain about. We state in the text that the short-term gain of the Funding Loan was 37\%. This number was calculated as follows. On the Funding Loan's day of issue, holders of the 1895 5\% Brazilian securities received - in lieu of a coupon-one Funding security for every four bonds. Because the $5 \%$ Brazilian bonds then stood at $£ 61$, the cost of replacing them with the Funding security was $4 \times £ 61=£ 244$ each. On the first day that Funding bonds were quoted 
(September 3), each $5 \%$ bond traded at $£ 62.75$ while funding bonds were sold at $£ 80$. By that date, the first of five coupons had been paid. The portfolio's value was thus $£ 336$ for a gain of $£ 92$, which represents an increase of $92 \div 244=37.7 \%$.

Let's now compare the returns to investors under a hypothetical scenario in which no restructuring or moratoria occurred. We do this by calculating the ex post internal rates of return (IRRs) of a portfolio consisting of four 1895 5\% Brazilian bonds and then comparing the Funding Loan scenario with the non-Funding, no-default scenario. (Of course, without the Funding there might have been a default, but we seek to compare what investors would have legitimately expected given that Rothschilds securities were quasi-risk-free.)

The IRR is calculated as the constant compounded rate that equalizes the product of actual annual rates of returns. ${ }^{67}$ The IRR gives an indication of the long-term performance of a bond during its lifetime. ${ }^{68}$ Examining these rates for the totality of Brazilian external bonds during the $19^{\text {th }}$ and early $20^{\text {th }}$ centuries, Abreau (2006) concludes that the general performance was higher than American or British bonds (albeit with a higher standard deviation). Abreu (2002) focuses on the Brazilian funding loans that took place in 1898, 1914, and 1931 and demonstrates that the IRRs for these loans were much higher than those on other, risk-free assets (U.K. and U.S. bonds).

Table A.1. Internal Rate of Return for 1895 Bond under Alternative Scenarios

\begin{tabular}{|l|l|l|l|l|}
\hline Bonds & $\begin{array}{l}18955 \% \text { with } \\
\text { Funding Loan } \\
\text { since June 1898 }\end{array}$ & $\begin{array}{l}\text { Counterfactual: 1895 } \\
5 \% \text { without Funding } \\
\text { Loan since June } \\
1898\end{array}$ & $\begin{array}{l}18955 \% \text { since } \\
\text { issue date with } \\
\text { Funding Loan }\end{array}$ & $\begin{array}{l}\text { Counterfactual: } \\
\begin{array}{l}18955 \% \text { since } \\
\text { issue date without } \\
\text { Funding Loan }\end{array}\end{array}$ \\
\hline IRR & $32.0 \%$ & $14.4 \%$ & $11.5 \%$ & $3.3 \%$ \\
\hline
\end{tabular}

Source: Authors' computations (see Appendix text).

We construct our IRR as follows. First we look at the precise conditions under which a bondholder of Brazilian bonds could exchange his coupons with Funding bonds, and then we look at the performance of the four 5\% 1895 bonds. Next we compare this performance with a counterfactual scenario in which the investor continued to receive punctual payments of coupons.

The conditions of the Funding Loan required an investor to present the coupons of the defaulting bonds as they became due for exchange into Funding bonds during the period of the "moratorium" (three years between 1898 and 1901). ${ }^{69}$ These Funding bonds were listed securities that provided an annual 5\% interest rate in cash and were to be amortized by a sinking fund of $0.5 \%$ yearly. This means that any calculation of the IRR should take into account price changes for both the 5\% 1895 bonds and the Funding bonds that an investor would successively receive as well as the coupon payments for these bonds. We focus on the years during which the Funding bonds were issue; that is, we begin our computations in June 1898 and continue until 1901. Taking a longer time horizon does not affect the basic results. We also compute IRRs since the issue date of the $18955 \%$ bonds. All results are shown in Table A.1.

The differences in IRRs are striking. If we concentrate only in the Funding Loan period, the ex post IRR with Funding Loan more than doubles the counterfactual no-default scenario (second and third columns). ${ }^{70}$ The last two columns measure IRRs since the issue date of the 5\% 1895 bonds. The values are lower because prices decreased continuously in the years previous to 1898 . Still, the

\footnotetext{
${ }^{67}$ If we denote by $t_{0}$ the date of issue, by $p_{t}$ the price in late December of year $t$, by $p_{t+1}$ the price in late December of year $t+1$, and by $d_{t+1}$ the dividend paid during year $t+1$, then the annual rate of return is $r_{t+1}=\left(d_{t+1}+p_{t+1}-p_{t}\right) / p_{t}$. We thus have $\prod_{t=t_{0}}^{1830}(1+\rho)^{1830-t_{0}}=\prod_{t=t_{0}}^{1830}\left(1+r_{t}\right) \square$ which can be solved for $\rho$.

${ }^{68}$ See Flandreau and Flores (2009), who adopt the same method advanced by Eichengreen and Portes (1989).

${ }^{69}$ The Funding Loan also suspended the sinking fund, and redemption of the defaulting loans was suspended for 13 years.

${ }^{70}$ Strictly speaking, our calculations do not exactly measure the same IRR: we take into account both the old 5\% 1895 bonds and the Funding bonds, whereas Abreu takes into account only the price movements and coupons received of the Funding bonds. Nonetheless, the $32 \%$ IRR is comparable to Abreu's (2002) calculations of the average yearly ex post IRR for the totality of the Funding bonds life, which imply maximum annual IRRs of 29.14\% (Abreu 2002, p. 537, Table 5).
} 
difference is substantial and demonstrates that, in any case, investors did obtain major gains by keeping the old bonds during these crisis years. 
Figure 1. Brands, Risk, and Performance in the mid- $19^{\text {th }}$-Century Debt Crisis (units for both axes, interest rates in percentage points)

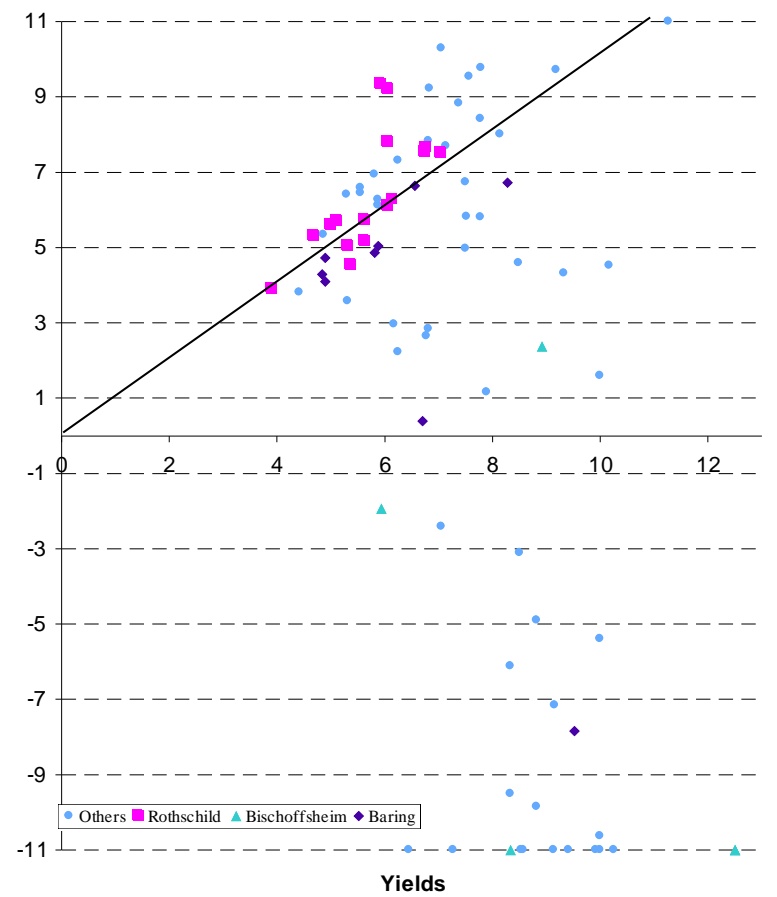

Source: Authors' computations from authors' database. 
Figure 2. Turnover and Spreads

(Units for $\mathrm{x}$-axis: percent; $\mathrm{y}$-axis: interest spreads in percentage points

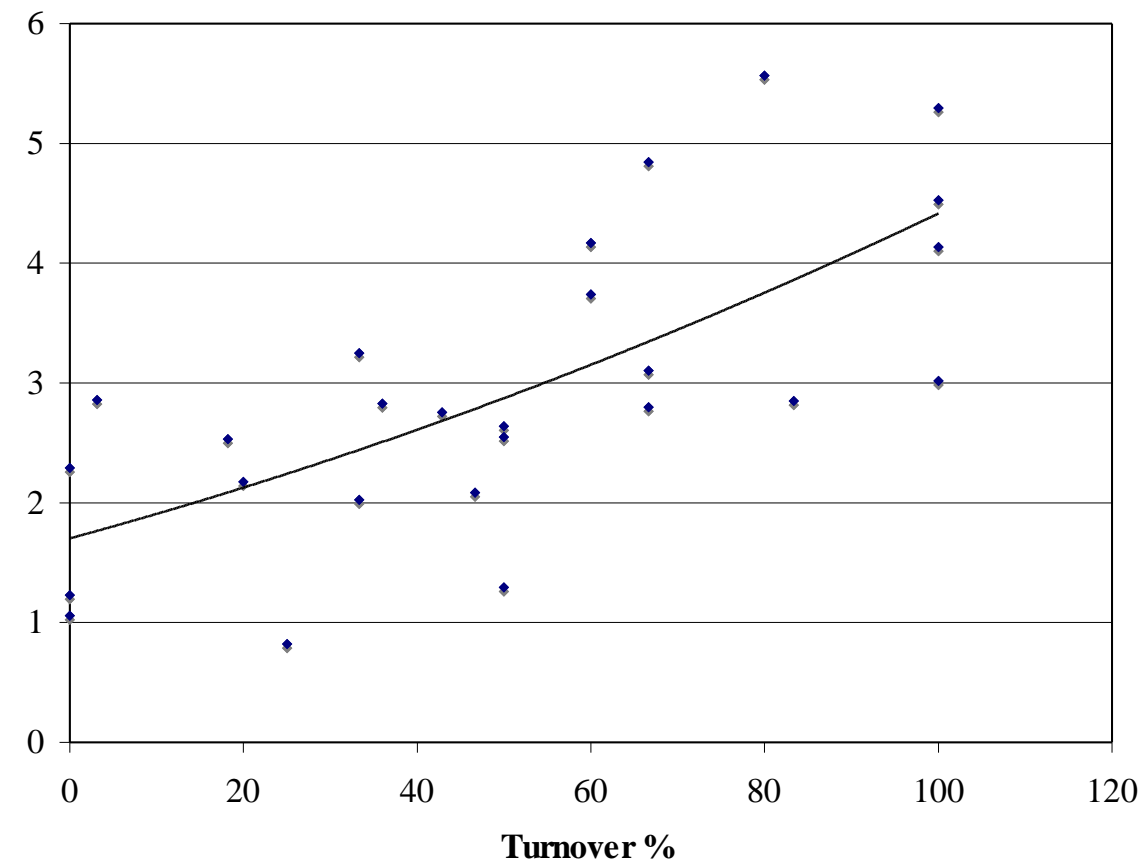

Source: From Flandreau et al. (2010). 
Figure 3. Countercyclical Prestige: Rothschilds' Market Shares during Booms and Busts (units: market share in \%)

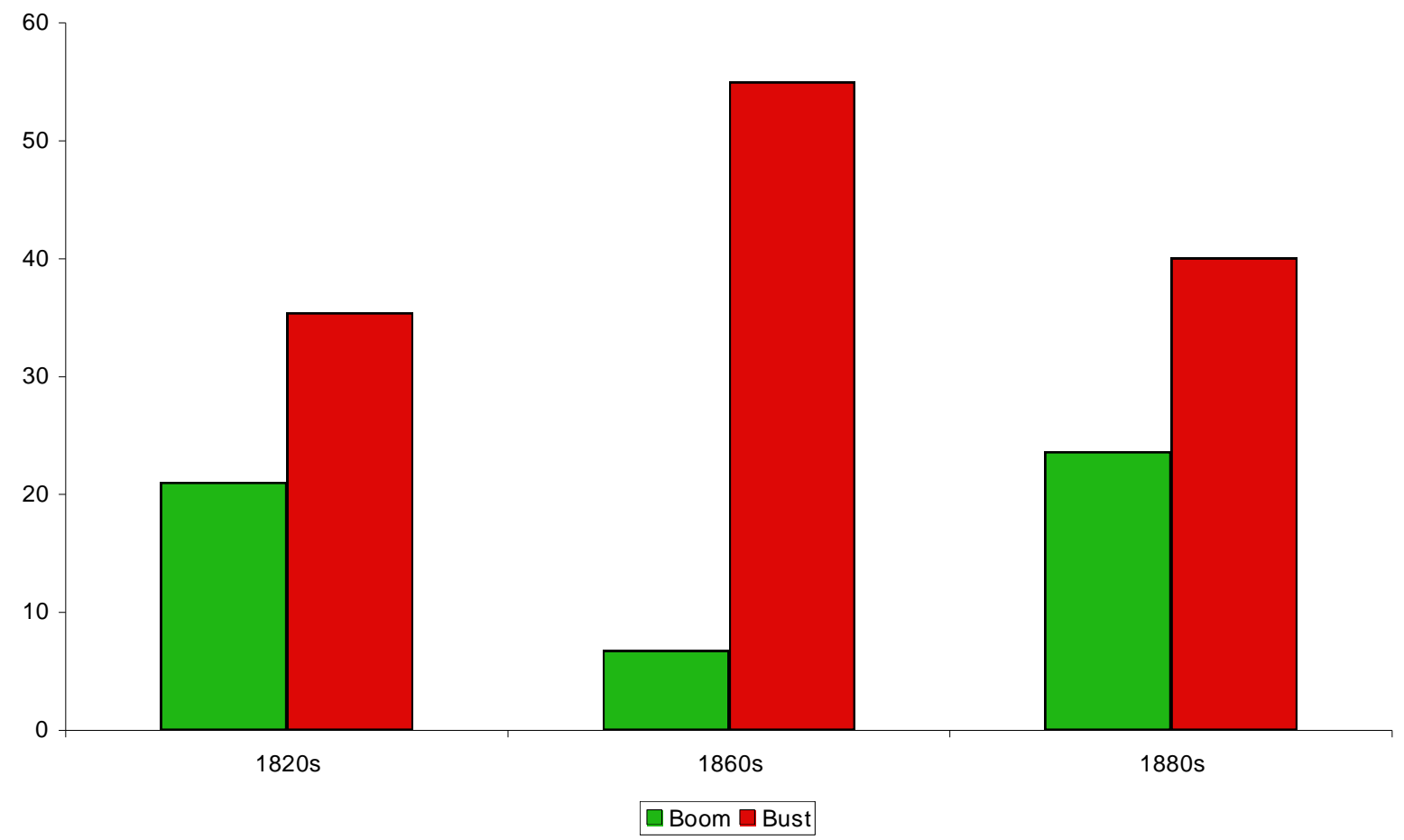

Source: Authors' computations from authors' database.

Note: Boom and bust periods were assigned as follows: for " $1820 \mathrm{~s}$ ", boom $1821-1825$ and bust 1826-1838; for "1860s", boom 1864-1870 and bust 1871-1877; for "1880s", boom 1878-1888 and bust 1889-1896. 
Figure 4. Bondholders' Actions and Government Bonds (Units: bond prices in sterling)

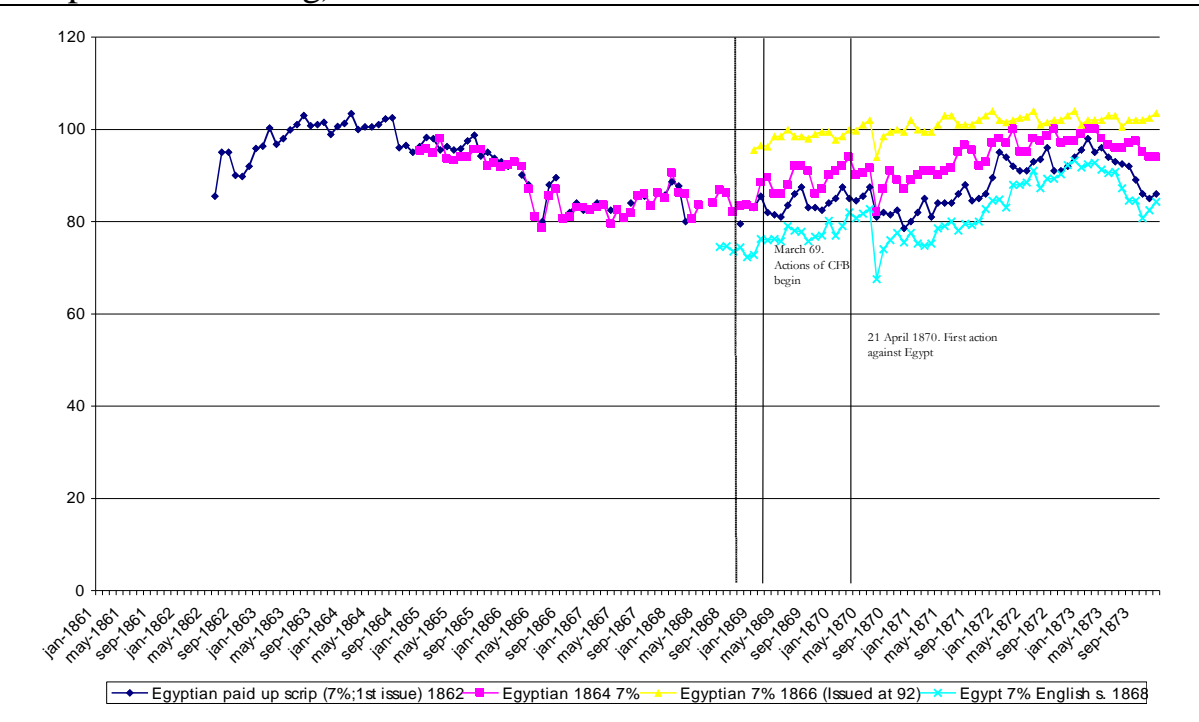

Figure 4a. Egypt

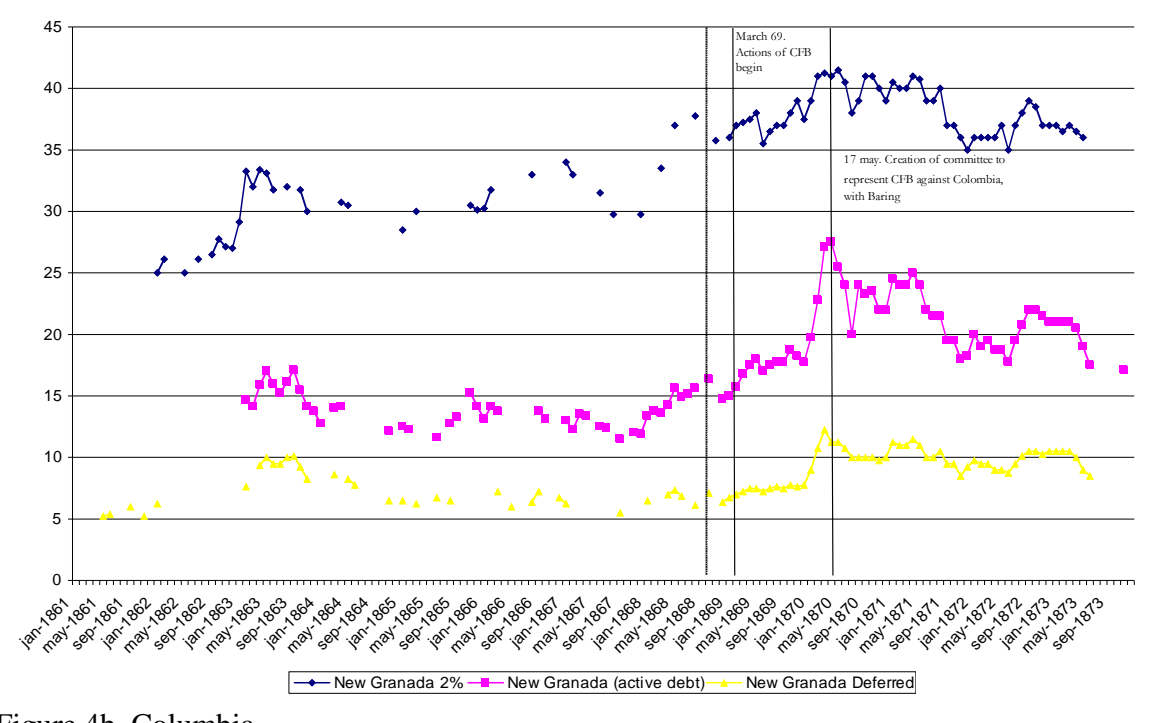

Figure 4b. Columbia

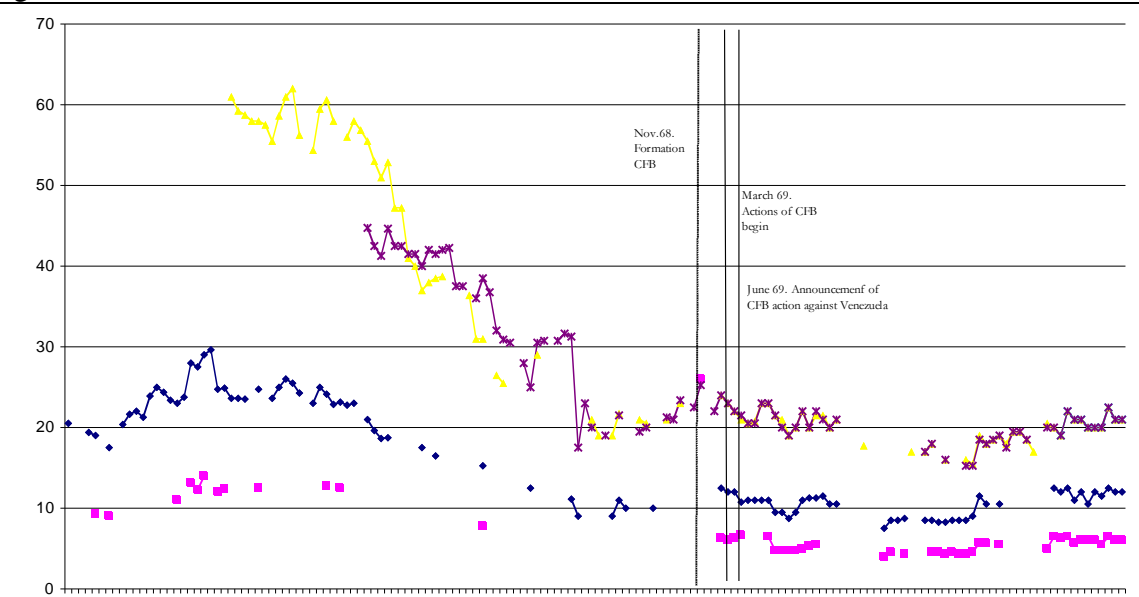

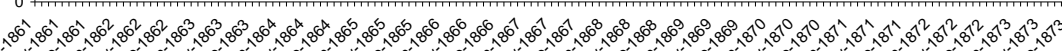
की

$\rightarrow$-Venezuela $3 \%$ - - Venezuela 1 1/2\% $\quad$ Venezuela $6 \% 1862 *$ Venezuela $6 \%$ issued for arrears $*$-Venezuela $6 \% 1864$

Figure $4 \mathrm{c}$ Venezuela 
Figure 5. Effects of Announcement of Barings's Agency on Mexican Bonds (units: interest rates in percentage points)

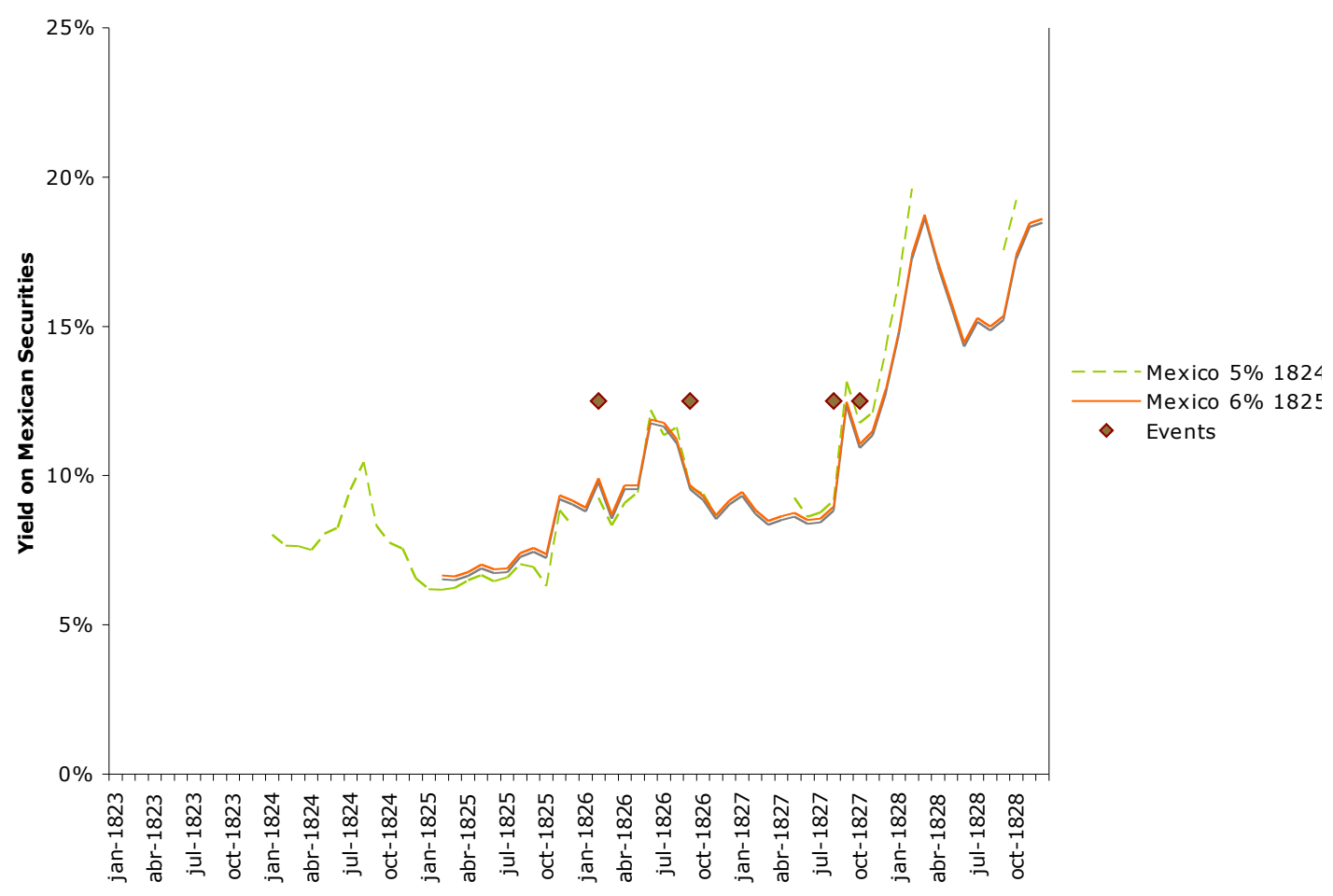

Source: Authors' computations based on data from Wetenhall's Course of Exchange and The Times. 
Table 1. Brazilian Issues, 1850-1914

\begin{tabular}{|l|l|l|l|l|}
\hline Year and coupon & $\begin{array}{c}\text { Date of } \\
\text { issue }\end{array}$ & Spread at issue & $\begin{array}{c}\text { Nominal amount } \\
\text { (£ million) }\end{array}$ & Underwriter \\
\hline $18524.5 \%$ & Jul 1852 & 1.7 & 1 & Rothschilds \\
\hline $18584.5 \%$ & May 1858 & 1.6 & 1.5 & Rothschilds \\
\hline $18604.5 \%$ & Mar 1860 & 1.8 & 1.4 & Rothschilds \\
\hline $18634.5 \%$ & Oct 1863 & 1.9 & 3.9 & Rothschilds \\
\hline $18655 \%$ & Sept 1865 & 3.4 & 6.9 & Rothschilds \\
\hline $18715 \%$ & Feb 1871 & 2.3 & 3.4 & Rothschilds \\
\hline $18755 \%$ & Jan 1875 & 1.9 & 5.3 & Rothschilds \\
\hline $18834.5 \%$ & Jan 1883 & 2.2 & 4.6 & Rothschilds \\
\hline $18865 \%$ & Feb 1886 & 2.5 & 6 & Rothschilds \\
\hline $18884.5 \%$ & Apr 1888 & 2 & 6 & Rothschilds \\
\hline $18894 \%$ & Oct 1889 & 1.8 & 20 & Rothschilds \\
\hline $18935 \%$ & Apr 1893 & 3.7 & 2.7 & Rothschilds \\
\hline $18955 \%$ & Jul 1895 & 3.5 & 7.4 & Rothschilds \\
\hline 1898 Funding 5\% & Jun 1898 & N.A. & 8.6 & Rothschilds \\
\hline $19014 \%$ & Mar 1901 & N.A. & 14.6 & Rothschilds \\
\hline $19035 \%$ & May 1903 & 2.8 & 5.5 & Rothschilds \\
\hline $19055 \%$ & Jun 1905 & 2.3 & 3 & Rothschilds \\
\hline $19065 \%$ & Apr 1906 & 2.4 & 1.1 & Rothschilds \\
\hline $19075 \%$ & Oct 1907 & 2.2 & 3 & Rothschilds \\
\hline $19085 \%$ & Jul 1908 & 2.3 & 4 & Rothschilds \\
\hline $19104 \%$ & May 1910 & 1.4 & 1 & Rothschilds \\
\hline $19104 \%$ & Feb 1910 & 1.5 & 10 & Rothschilds \\
\hline $19135 \%$ & May 1913 & 1.8 & 11 & Rothschilds \\
\hline & & & & \\
\hline
\end{tabular}

Source: Authors' database (see description in text).

Note: One small corporate loan issued in 1911 and underwritten by the South American Railway Construction Company, related to Lloyds Bank and including special guarantees, is not included. 
Table 2. The 1840s U.S.State Debt Crisis and the House of Barings

\begin{tabular}{|c|c|c|c|c|}
\hline State's type (a) & $\begin{array}{l}\text { London Window } \\
1838 \text { (b) }\end{array}$ & $\begin{array}{l}\text { London Window } \\
1856 \text { (c) }\end{array}$ & Barings' Action (d) & Outcome (e) \\
\hline \multicolumn{5}{|c|}{ NON-DEFAULTERS (WITH A DEBT LISTING IN LONDON ACCORDING TO SOURCES) } \\
\hline Alabama & $\begin{array}{l}\text { - Th. Wilson, Irving } \\
\text { Reid }\end{array}$ & $\begin{array}{l}\text { - Rothschild } \\
\text { - Union Bank of } \\
\text { London } \\
\end{array}$ & No need & -- \\
\hline Georgia & -- & • "In London" (f) & No need & -- \\
\hline Massachusetts & -- & - Baring & No need & -- \\
\hline New York & • "In London" & -- & No need & -- \\
\hline South Carolina & -- & $\begin{array}{l}\text { - Baring } \\
\text { - Palmer, Mackillop \& } \\
\text { Dent } \\
\end{array}$ & No need & -- \\
\hline Virginia & -- & - Baring & No need & -- \\
\hline \multicolumn{5}{|c|}{ TEMPORARy DEFAULT } \\
\hline Illinois & -- & -- & $\begin{array}{l}\text { Barings campaign with } \\
\text { others }\end{array}$ & $\begin{array}{l}4 \text { years: Resumption } \\
1846\end{array}$ \\
\hline Indiana & $\begin{array}{l}\text { - Morrisson, Cryder } \\
\text { and Co }\end{array}$ & -- & $\begin{array}{l}\text { Butler: New York } \\
\text { Businessman }\end{array}$ & $\begin{array}{l}6 \text { years: Resumption } \\
1847\end{array}$ \\
\hline Maryland & -- & - Baring & $\begin{array}{l}\text { Barings wages costly } \\
\text { campaign }\end{array}$ & $\begin{array}{l}6 \text { years: Resumption } \\
1848\end{array}$ \\
\hline Pennsylvania & -- & - Wiggin and Co & $\begin{array}{l}\text { Barings leads heavy } \\
\text { "attack" with other } \\
\text { banks }\end{array}$ & $\begin{array}{l}3 \text { years: Resumption } \\
1845\end{array}$ \\
\hline \multicolumn{5}{|c|}{ PARTIAL REPUDIATION } \\
\hline Arkansas & -- & -- & $\begin{array}{l}\text { Barings ignore, Huth } \\
\text { makes efforts }(\mathrm{g})\end{array}$ & No arrangement \\
\hline Louisiana & - Baring & • "In London" & $\begin{array}{l}\text { Barings with help of } \\
\text { Lizardi }\end{array}$ & $\begin{array}{l}\text { Restoration of credit } \\
\text { (h) }\end{array}$ \\
\hline Michigan & -- & -- & $\begin{array}{l}\text { Butler, New York } \\
\text { Businessman }\end{array}$ & $\begin{array}{l}8 \text { years: Resumption } \\
1849\end{array}$ \\
\hline \multicolumn{5}{|c|}{ TOTAL REPUDIATION } \\
\hline Florida Territory & - Thomas Wilson & -- & $\begin{array}{l}\text { Barings ignore, } \\
\text { Palmer, McKillop \& } \\
\text { Dent makes effort (g) } \\
\end{array}$ & Repudiation, 1842 \\
\hline Mississippi & - Thomas Wilson & - Thomas Wilson & $\begin{array}{l}\text { Very weak Barings' } \\
\text { campaign with Huth (i) }\end{array}$ & Repudiation, 1842 \\
\hline
\end{tabular}

(a) English (1996).

campaign with Huth (i)

(b) Fortune's Epitome (1838).

(c) Fortune's Epitome (1856).

(d) McGrane (1935), Hidy (1949).

(e) McGrane (1935), Hidy (1949), Kim and Wallis (2005).

(f) The Times (26 February 1851) states that Irving, Ebsworth, and Holmes are paying the coupon.

(g) "[Barings] displayed no interest whatsoever in Florida and Arkansas" (Hidy 1949, p. 339).

(h) "By 1848, credit of ... reasonably well resuscitated" (Hidy 1949, p. 335).

(i) Mississippi: "Restoration of good faith ... always seemed so remote that B. never gave more than halfhearted support" (Hidy 1949, p. 336). 